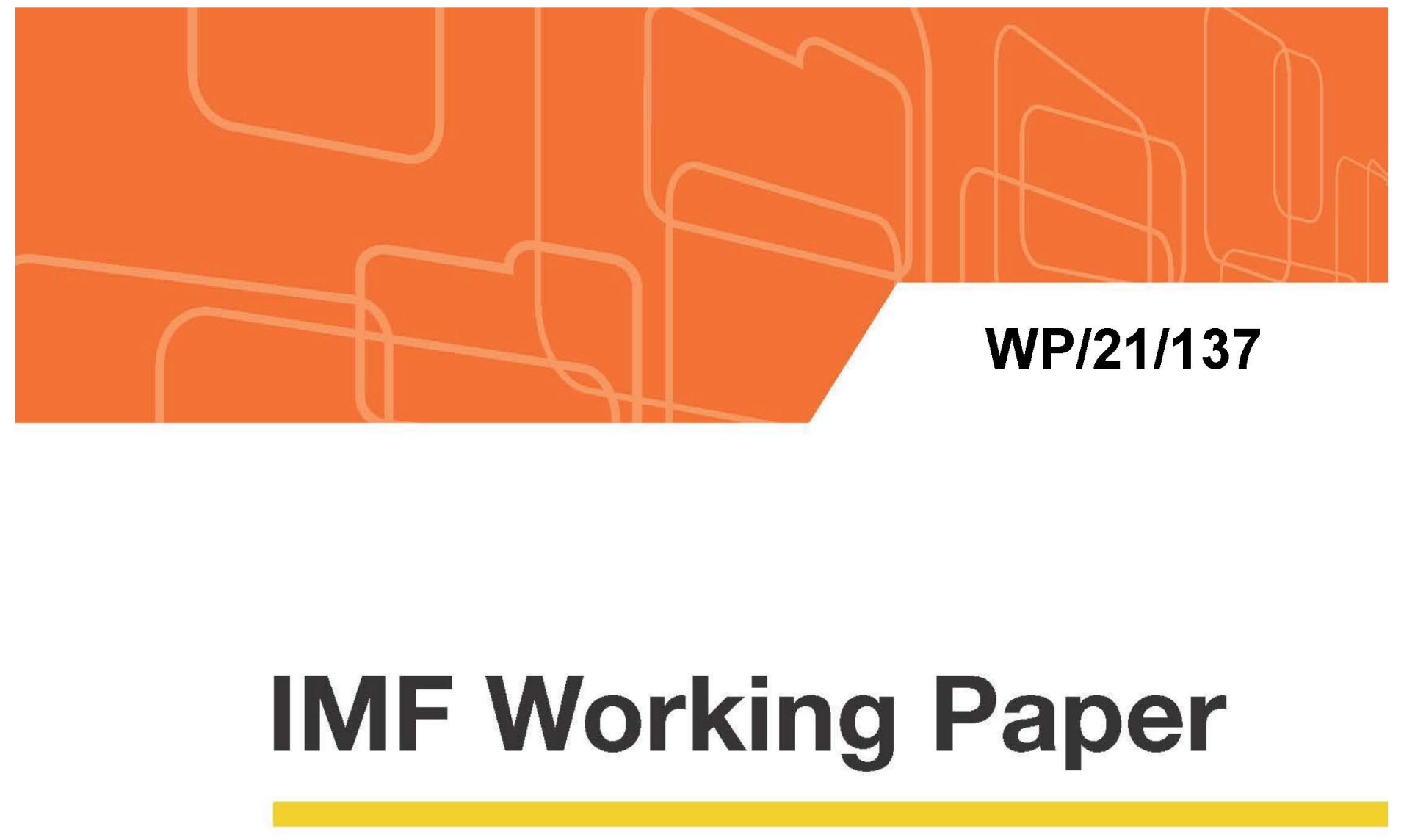

\title{
Determinants of and Prospects for Market Access in Frontier Economies
}

by Victor Hugo C. Alexandrino da Silva, Luiza Antoun de Almeida and Diva Singh

IMF Working Papers describe research in progress by the author(s) and are published to elicit comments and to encourage debate. The views expressed in IMF Working Papers are those of the author(s) and do not necessarily represent the views of the IMF, its Executive Board, or IMF management. 


\title{
IMF Working Paper
}

Strategy, Policy and Review Department

\section{Determinants of and Prospects for Market Access in Frontier Economies}

\author{
Victor Hugo C. Alexandrino da Silva, Luiza Antoun de Almeida and Diva Singh ${ }^{1}$ \\ Authorized for distribution by Bikas Joshi
}

May 2021

\begin{abstract}
IMF Working Papers describe research in progress by the author(s) and are published to elicit comments and to encourage debate. The views expressed in IMF Working Papers are those of the author(s) and do not necessarily represent the views of the IMF, its Executive Board, or IMF management.
\end{abstract}

\begin{abstract}
In recent years, we have observed an increase in low-income countries' (LICs) access to international capital markets, especially after the Global Financial Crisis (GFC). This paper investigates what factorscountry-specific macroeconomic fundamentals and/or external variables - have contributed to the surge in external bond issuance by these LICs, which we refer to in our paper as 'frontier economies'. Using data on public and publicly guaranteed (PPG) external bond issuance, outstanding PPG bond stock, as well as sovereign spreads, we employ panel data analysis to examine factors related to the increase in issuance by these economies as well as the reduction in their spreads over time. Our empirical study shows that both country-specific fundamentals (such as public debt, current account balance, level of reserves, quality of institutions) and external variables (such as US growth and the VIX index) play a role in explaining the increased amount of issuance and the decline in spreads of frontier economies' sovereign bonds. The impact of some of these variables on issuance appears to reflect a country's need to issue bonds for external financing ('the supply side' of bond issuance), while others appear to correlate more through their impact on investors' appetite for a country's debt ('the demand side'). In addition, the impact of country-specific variables can also be affected by external factors such as global risk appetite. Our analysis of key factors that have contributed to increased market access for frontier economies over the past decade provides important information to gauge the prospects for their continued market access, and for other LICs to join this group by tapping international markets for the first time.
\end{abstract}

JEL Classification Numbers: F34; G12; G15; O11.

Keywords: Sovereign bond issuance; Frontier markets; Market access; Bond spreads.

Authors’ email addresses: vhalexs@gmail.com ; lantoundealmeida@imf.org; dsingh@imf.org

\footnotetext{
${ }^{1}$ Victor Hugo C. Alexandrino da Silva is a Ph D. Candidate at the Insper Institute of Education and Research. The authors are extremely grateful to Bikas Joshi and Daehaeng Kim for their guidance and fruitful discussions, and to Yudong Rao for excellent research assistance. The authors would also like to thank the participants of the SPR Seminar at the IMF for their helpful comments.
} 


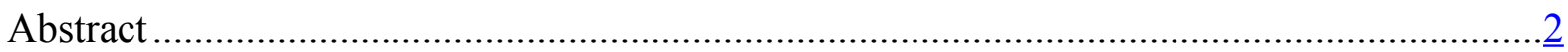

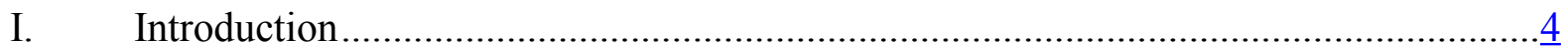

II. Literature Review..........................................................................................

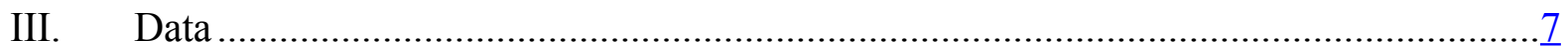

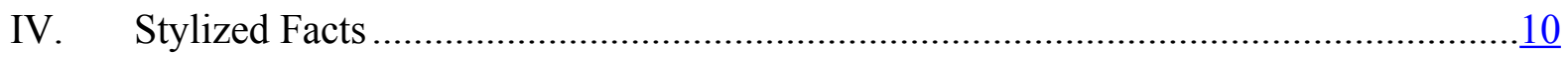

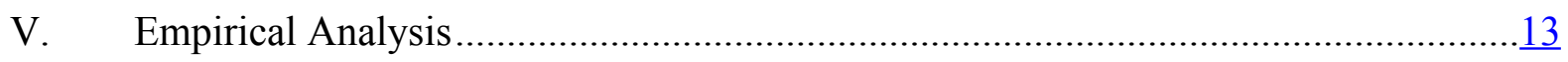

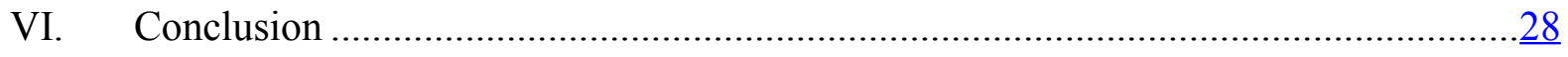

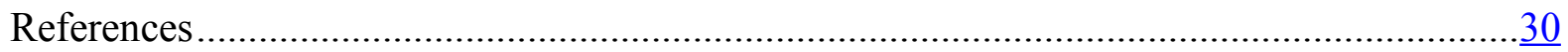

Tables

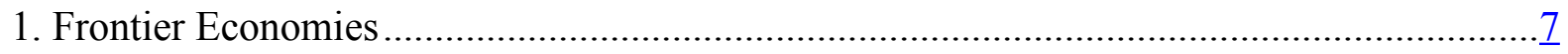

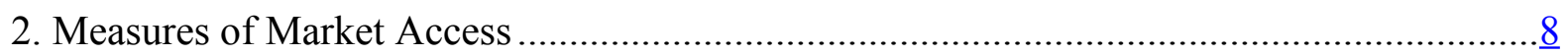

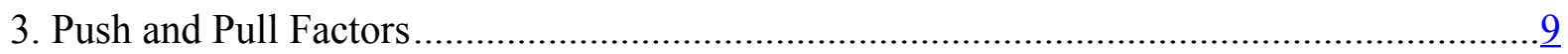

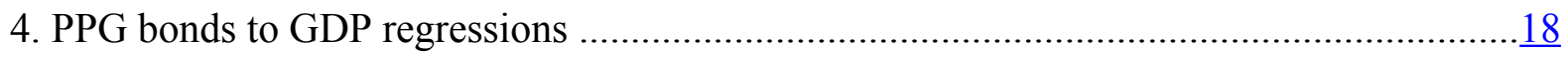

5. Probability of Issuance regressions - Non-Linear Marginal Effects ...................................19

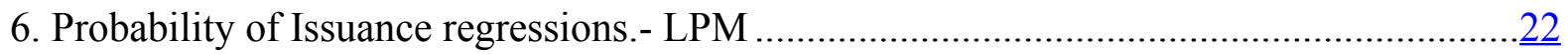

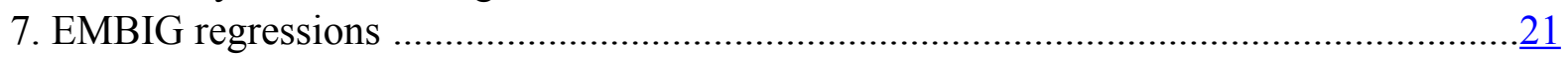

8. Factors Affecting Market Access in EE vs Frontier Economies ........................................26

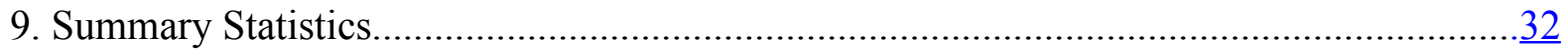

Figures

1. Outstanding PPG Bond Stock in Frontier Economies - 1990 to 2019 …...........................10

2. Frequency of PPG Issuance by Frontier Economies......................................................11

3. Outstanding PPG Bond Stock vs VIX - 2009 to 2019 …...............................................

4. EMBIG spreads evolution in Frontier Economies ........................................................

5. Number of issuances by year and country …………...................................................

6. Percentage of Correct Predictions of PPG Issuance ……................................................ 23

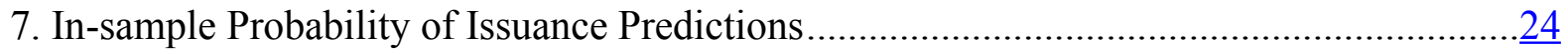




\section{INTRODUCTION}

In recent years, we have seen a new group of low-income economies increasingly issue sovereign debt in international capital markets. These countries typically occupy the higher end of the income spectrum for low-income countries (LICs) and are referred to in this paper as frontier economies. ${ }^{2}$ Not only has the amount of issuance by individual frontier economies been increasing, but the number of these countries that have been able to access international sovereign markets has also seen a notable spike, especially in the last ten years.

What is more, the continuous decline in frontier economies' EMBI spreads ${ }^{3}$ in recent years suggests that they have not only broken into the international capital markets arena but appear to be welcome participants in it. Since sovereign spreads against benchmark US Treasury rates can be seen as a real-time gauge of country risk, the compression of frontier economies' spreads suggests a reduction in the perceived risk of investing in these countries, or conversely, an increase in investors' appetite for their government debt.

This paper attempts to analyze the drivers of these trends. In particular, we study whether domestic macroeconomic fundamentals or external factors, such as global market volatility, US growth and interest rates, have been the main impetus for frontier economies' increased market access and declining spreads in the post-Global Financial Crisis decade. We also seek to answer whether bond issuance by frontier economies has been driven more by their rising financing needs (the supply-side) or by investors' appetite for their bonds (the demand side).

Our main results show that both country-specific macroeconomic factors and external variables are relevant in explaining frontier economies' increased access to international capital markets. However, the results vary depending on how market access is defined. For example, when we define market access as the outstanding stock of frontier economies' external bond debt, a proxy for the cumulative volume of issuance, this appears to be related to both investors' demand for bonds and frontier economies' financing needs. But when we look instead at the probability of bond issuance in a given year as a gauge for market access, this seems to depend more critically on investors' demand for a country's debt at that juncture. Finally, if we take sovereign spreads as an indicator of market access - being an indicator of country risk that reflect the cost of issuance - these respond to both domestic and external factors that impact investors' risk appetite.

Our analysis contributes to the literature on developing economies' market access in various ways, but perhaps most notably through its focus on frontier economies rather than conventional emerging markets. By investigating whether domestic macroeconomic fundamentals or external factors such as global liquidity and risk aversion have been more critical to frontier economies' increased market access over the past decade, we are able to examine the role that policies may have played in the evolution of their debt markets. The use of three different proxies for market access also enriches our analysis by allowing us to study different dimensions of market access.

\footnotetext{
${ }^{2}$ We define frontier economies in this paper as LICs that have had market access from the period 1990-2019. See Section III.

${ }^{3}$ JP Morgan's Emerging Market Bond Index Global (EMBIG).
} 
Finally, we explore how our findings on the determinants of frontier economies' market access over the past decade could help inform a forward-looking assessment of their prospective market access. Such an assessment could be useful not only for frontier economy authorities to gauge financing prospects, but also for multilateral institutions such as the IMF in determining whether a LIC (that may or may not have issued sovereign bonds in the past) has access to international capital markets at a given juncture - a key factor for some of the IMF's LIC lending operations (Box I).

This paper is divided into six sections. Section II summarizes the literature related to this work. Section III presents our dataset and key definitions. In Section IV, we depict some stylized facts to illustrate the evolution of frontier economies' access to international capital markets. Finally, Section V presents our empirical strategy and main results, along with some robustness checks, and Section VI concludes.

\section{Box 1. The IMF Low-Income Country Facilities Framework*}

The IMF's Low-Income Country (LIC) Facilities framework was established in 2009 with the objective of providing concessional financing to poorer and more vulnerable member countries. The framework includes three lending facilities and one non-financial instrument. Loans to LICs via these facilities are currently provided at zero interest rates until at least end-June 2021 through the IMF-administered Poverty Reduction and Growth Trust (PRGT), which operates on a self-sustaining basis, with income from investments of the trust covering the subsidy costs of concessional lending. To maintain the viability of the trust fund, there are limits on the size of PRGT loans. The LIC facilities framework determines which IMF members can access PRGT resources based on an assessment of their level of income per capita, access to international financial markets, and the existence and severity of short-term vulnerabilities. ${ }^{1 /}$ Every two years, a review of members' eligibility to access the PRGT is conducted based on a transparent and rule-based framework, with the aim of recommending which members should enter into or graduate from the PRGT-eligible list.

The criteria for member countries' entry into and graduation from the PRGT-eligible list are differentiated, with the latter being more stringent in order to minimize the risk of reverse-graduation. Countries enter the list if their income per capita is below a certain threshold and they do not have access to international financial markets on a durable and substantial basis. Countries are expected to graduate from the list when they have achieved income per capita levels above a certain threshold for a specified period, or have established access to international financial markets on a durable and substantial basis (and have income above a certain threshold), and do not face serious short-term vulnerabilities. Furthermore, to ensure the targeting of scarce PRGT resources to the most vulnerable, prior to reaching the graduation stage, LICs with income per capita above a certain threshold, substantial access to international financial markets, and low-tomoderate debt risks are only able to tap concessional resources in a blend with non-concessional resources. ${ }^{2 /}$ Higher-income LICs with substantial past market access that are at high risk of debt distress are also presumed to blend, but only if they are deemed to have prospective market access in light of debt risks.

Assessing whether an IMF member country has past and prospective market access is therefore critical for the PRGT lending framework. While there are clearly laid out rules to determine past market access, ${ }^{3 /}$ the assessment of prospective market access for countries at high risk of debt distress relies mainly on the assessment of forward-looking debt vulnerabilities and judgement. The analysis on determinants of frontier economies' market access in this paper provides useful information to help inform this judgment.

*This box was based on IMF (2020), "Eligibility to Use the Fund's Facilities for Concessional Financing, 2019" (SM/19/27).

1/ A few small and micro-states are also included on account of their size and vulnerabilities.2/ PRGT-eligible members meeting the income or market access criteria for blending should tap Fund resources in a blend of concessional PRGT resources with non-concessional GRA resources in a ratio of $1: 2$.

3/ Depending on the rating of debt distress, the assessment of past market access on a durable and sustainable basis is determined by whether a member has borrowed from international financial markets in two/three of the last five years in a cumulative amount of at least $25 / 50$ percent of quota. 


\section{Literature REVIEW}

This paper builds on an extensive literature on the drivers of international market access among emerging markets and extends the analysis to cover the recent surge in bond issuance by frontier economies. The first challenge that our paper seeks to overcome is finding an accurate measure of market access that accounts for its multiple dimensions, such as price, quantity, and frequency. Previous studies, such as IMF (2020) and Guscina et al (2017), provide different definitions of market access and the loss thereof. IMF (2020) considers a low-income country to have sustainable and durable access to international capital markets if it has issued international bonds in three out of the past five consecutive years in a cumulative amount of at least 50 percent of its IMF quota. Guscina et al (2017) find that, among other factors, a significant deterioration in sovereign spreads, nonresident holdings of public debt, rollover rates, sovereign credit ratings, and government cash balances are all leading indicators for loss of market access.

The literature typically identifies two main drivers of emerging markets' access to international capital markets. On the one hand, 'pull' factors are country-specific characteristics that may spark or thwart investors' interest. These factors include macroeconomic fundamentals such as fiscal performance, external sustainability, income level, growth, private sector development, quality of governance and institutional characteristics. On the other hand, 'push' factors are exogenous external variables, such as global market volatility and the US policy rate, which may impact investors' risk appetite and borrowing decisions.

Most papers (Comelli et al, 2012; Gelos et al, 2011; Presbitero et al, 2015) find that both, country-specific macro fundamentals as well as external factors, influence the capacity of emerging markets to tap international capital markets. Studies, such as Presbitero et al (2015) and Min et al (2003), show that countries with stronger fiscal and external balances, sound institutions, and solid liquidity and solvency positions are more likely to access international capital markets. In addition, Comelli et al (2012) and Fratzscher (2012) report that the impact of domestic fundamentals on market access depends on external factors. Comelli et al (2012) find that the impact of domestic fundamentals is diminished at times of high global market volatility relative to more stable periods. In a similar vein, Fratzscher (2012) shows that while push factors were the main drivers of capital flows during the GFC, country-specific determinants have become more important in defining the post-GFC sovereign borrowing dynamics. Interestingly, Gelos et al (2011) document that not only is the probability of market access not influenced by the frequency of defaults but also that a default, if resolved quickly, does not necessarily reduce the probability of tapping markets.

As LICs' access to international capital markets is a relatively recent phenomenon, analysis of this trend is more limited and often coincides with discussions on international investment diversification. Mecagni et al (2014) examine the increase in international bond issuance by African frontier economies, exploring the role of issuance in financing structural investment in these economies on the one hand, and the portfolio diversification opportunity presented to international investors on the other. On the latter, they conclude that maintaining a sound fiscal environment is paramount to attract investor demand. Similarly, Haque et al (2017) find that maintaining a strong growth performance and a favorable sovereign rating increase LICs' 
chances to access international capital markets. They also caution that LICs with access to capital markets must implement policies to prevent excessive borrowing and ensure sound debt management (as investors in search for yield may ignore weakening fundamentals until too late). Berger et al (2011) provide empirical evidence that frontier markets' exchange-traded funds have low integration with the world and thereby offer investors an important diversification tool.

Finally, several previous papers study whether receiving financial support from international financial institutions (IFIs), such as the World Bank and IMF, can help catalyze funding from other sources, including international capital markets. The conclusions vary. While Gelos et al (2011) find no catalytic effect from IMF-supported programs, Presbitero et al (2015) find that IMF support is associated with a higher likelihood of an emerging market issuing an international bond. Somewhat distinctly, Corsetti et al (2006) use a theoretical game theory model to show that financial support from IFIs can help prevent a destructive bank run in LICs and that these effects are stronger the larger the size of the support.

\section{DATA}

Our panel dataset consists of annual data for 18 frontier economies from 1990 to 2019. Frontier economies are defined as LICs that fulfill the following two criteria: i) income criterion: countries that are $\mathrm{PRGT}^{4}$ and/or $\mathrm{IDA}^{5}$ eligible, excluding economies that are only eligible because of their small economy status, and ii) market access criterion: countries that have issued public and publicly guaranteed (PPG) external bonds at least once between 1990 and 2019. External bond debt according to the World Bank's International Debt Statistics (IDS) definition consists of bonds held by nonresident creditors, which can be denominated in both foreign and domestic currency. The final list of countries includes 15 countries that are both PRGT and IDA eligible and 3 economies that are only IDA eligible, most of which (11 out of 18) are African countries. Table 1 summarizes our sample.

\section{Table 1. Frontier Economies}

\begin{tabular}{|c|c|}
\hline Countries & Eligibility \\
\hline $\begin{array}{c}\text { Cameroon, Cote d'Ivoire, Ethiopia, Ghana, Guinea, } \\
\text { Honduras, Kenya, Lao PDR, Mozambique, Moldova, } \\
\text { Papua New Guinea, Rwanda, Senegal, Tajikistan and } \\
\text { Zambia }\end{array}$ & PRGT and IDA \\
\hline Mongolia, Nigeria and Pakistan & IDA \\
\hline
\end{tabular}

The analysis uses three different proxies for market access: i) the outstanding PPG bond stock to GDP ratio; ii) the probability of issuance, a binary variable that is equal to 1 if a frontier economy has issued PPG bonds in a given year and equal to 0 if not; and iii) EMBI spreads.

\footnotetext{
${ }^{4}$ Poverty Reduction and Growth Trust, the IMF support arrangement for LICs. The latest eligibility criteria for PRGT funding are detailed in IMF (2020) Eligibility to Use the Fund's Facilities for Concessional Funding, 2019.

${ }^{5}$ International Development Association, the World Bank Group support arrangement for LICs. The latest IDA operational income cutoff is $\$ 1,185$ in fiscal year 2021. The operational threshold is revised on an annual basis every July.
} 
These different measures capture different dimensions of the concept of market access: for example, if a country can issue the quantity it wants to at a time when it needs to and at a cost that it can absorb, we can say that it enjoys market access; but all of these elements may not be satisfied at the same time. Thus, the three gauges of market access complement each other. The outstanding bond stock to GDP ratio is a proxy for the cumulative volume of issuance and contains information about the magnitude of issuance relative to the size of the economy. On the other hand, the probability of issuance variable captures the timing of issuance, independently of its size. When issuance is not observed in this model, however, we cannot explain whether this is because the country did not need financing or because it did not find investors' demand for its bonds. Finally, EMBI spreads contain information on investors' risk assessment of a country and the cost to the country of issuing debt; in particular, whether it is financially viable to issue.

EMBI spreads are only available for 12 countries in our sample that have more developed bond markets. Data on bond stocks and issuance comes from the World Bank Group's International Debt Statistics (IDS). We have chosen IDS as our source of bond issuance data as it provides complete standardized annual information on bond stocks and issuance and also has observations on LICs. Table 2 summarizes our dependent variables with their respective descriptions and sources.

\begin{tabular}{|c|c|c|}
\hline \multicolumn{3}{|c|}{ Table 2. Measures of Market Access } \\
\hline Variable & Description & Source \\
\hline PPG Bond Stock & $\begin{array}{c}\text { Outstanding PPG bond stock as } \\
\text { percent of GDP } \\
\text { A binary variable that is equal } \\
\text { to } 1 \text { if a frontier country has } \\
\text { issued PPG bonds in a given } \\
\text { year and equal to 0 otherwise. }\end{array}$ & $\begin{array}{c}\text { WBG International Debt } \\
\text { Statistics (IDS) } \\
\text { Probability of Issuance } \\
\text { EMBIG spreads }\end{array}$ \\
EMBIG Index & Statistics (IDS) \\
\hline
\end{tabular}

Table 3 describes our set of pull and push explanatory variables. The majority of our countryspecific data (pull factors) was collected from the IMF's World Economic Outlook (WEO, October 2020) and includes GDP per capita, GDP growth, fiscal balance, current account balance, reserve assets, government debt, external debt, terms of trade, inflation, and credit to the private sector. In addition, the quality of institutions is proxied by the World Bank's rule of law index from the World Governance Indicators (WGI) database. The indicator is in percentile rank, where 0 is the lowest bound and 100 is the highest rank, meaning better institutions. We also include a dummy for IMF financial support as a country-specific variable, which equals 1 if a country has an IMF financial arrangement in place $^{6}$ in a given year, and 0 if not. On the other side, external push factors include the US GDP growth rate, the US policy rate, 10-year Treasury bond yields and the VIX index. The US growth rate, policy rate, and 10-year bond yields should

\footnotetext{
${ }^{6}$ We include upper credit tranche PRGT and General Resources Account (GRA) arrangements as some of the countries in our sample are blenders (as described in Box I), and others were not PRGT-eligible for the entire time period.
} 
capture investors' chase for yield behavior. The CBOE volatility index (VIX) proxies volatility and risk aversion in global financial markets.

\begin{tabular}{|c|c|c|}
\hline \multicolumn{3}{|c|}{ Table 3. Push and Pull Factors } \\
\hline \multicolumn{3}{|c|}{ Pull factors (country-specific characteristics) } \\
\hline Variable & Unit & Source \\
\hline GDP per capita & Thousand US Dollars & IMF World Economic Outlook (WEO) \\
\hline GDP growth & Percent & IMF World Economic Outlook (WEO) \\
\hline Fiscal Balance & Percent of GDP & IMF World Economic Outlook (WEO) \\
\hline Current Account & Percent of GDP & IMF World Economic Outlook (WEO) \\
\hline Reserve Assets & Months of Imports & IMF World Economic Outlook (WEO) \\
\hline Government Debt & Percent of GDP & IMF World Economic Outlook (WEO) \\
\hline External Debt & Percent of GDP & IMF World Economic Outlook (WEO) \\
\hline Terms of Trade & US Dollars & IMF World Economic Outlook (WEO) \\
\hline Inflation & Percent & IMF World Economic Outlook (WEO) \\
\hline $\begin{array}{l}\text { Private Credit } \\
\text { Lending }\end{array}$ & Percent of GDP & $\begin{array}{l}\text { WBG World Development Indicators } \\
\text { (WDI) }\end{array}$ \\
\hline $\begin{array}{l}\text { Institutions (Rule } \\
\text { of Law) }\end{array}$ & $\begin{array}{c}\text { Percentile rank (0 lowest rank, } 100 \text { highest } \\
\text { rank) }\end{array}$ & WBG World Governance Indicators (WGI) \\
\hline IMF Support & $\begin{array}{l}\text { Dummy variable ( } 1 \text { if it received PRGT or } \\
\text { GRA support in a given year, } 0 \text { otherwise) }\end{array}$ & IMF Finance Department Database \\
\hline $\begin{array}{l}\text { IMF PRGT-ECF } \\
\text { Support }\end{array}$ & $\begin{array}{l}\text { Dummy variable ( } 1 \text { if it received PRGT-ECF } \\
\text { support in a given year, } 0 \text { otherwise) }\end{array}$ & IMF Finance Department Database \\
\hline $\begin{array}{l}\text { IMF PRGT-SCF } \\
\text { Support }\end{array}$ & $\begin{array}{l}\text { Dummy variable ( } 1 \text { if it received PRGT-SCF } \\
\text { support in a given year, } 0 \text { otherwise) }\end{array}$ & IMF Finance Department Database \\
\hline \multicolumn{3}{|c|}{ Push factors (global external characteristics) } \\
\hline Variable & Unit & Source \\
\hline $\begin{array}{l}\text { US policy interest } \\
\text { rate }\end{array}$ & Percent & Bloomberg \\
\hline $\begin{array}{l}\text { US Bond 10yr } \\
\text { yield }\end{array}$ & Percent & Bloomberg \\
\hline US growth & Percent & IMF World Economic Outlook (WEO) \\
\hline CBOE VIX Index & Index & Bloomberg \\
\hline
\end{tabular}

Finally, we would like to acknowledge some of the challenges we faced on the data front. First, since we are dealing with frontier economies that have only begun to access international markets in recent years, our dataset misses some observations for spreads and interest rates. We 
are also hostage to idiosyncrasies of the past decade. For example, as we will discuss in the next section, in our baseline identification strategy, we use US growth in place of the US policy rate as an explanatory variable since US interest rates have remained stable at historical lows since 2009. Second, since we are working with a relatively short timeframe, this could lead to goodness-of-fit issues in our main regressions.

\section{STYLiZEd FACTS}

This section presents some stylized facts on how market access has evolved in frontier economies in recent years. Four key trends stand out. First, frontier economies started to issue bonds in international capital markets after 1990, but the issuance really took off after 2009. Second, after the GFC, the proportion of bond issuance became more evenly distributed among our sample of frontier economies. Third, the increase in bond issuance after 2009 coincided with a decreasing trend in global financial market volatility. ${ }^{7}$ Lastly, frontier economies' sovereign spreads have narrowed during the period covered in our sample.

Frontier economies' outstanding stock of external PPG bond debt - a proxy for the cumulative volume of PPG external bond issuance - increased substantially between 1990 and 2019, particularly after the GFC (Figure 1). While the total amount of frontier economies' outstanding external PPG bonds stood at USD 4.5 billion at end-2009, this increased to USD 55.9 billion by end-2019. ${ }^{8}$

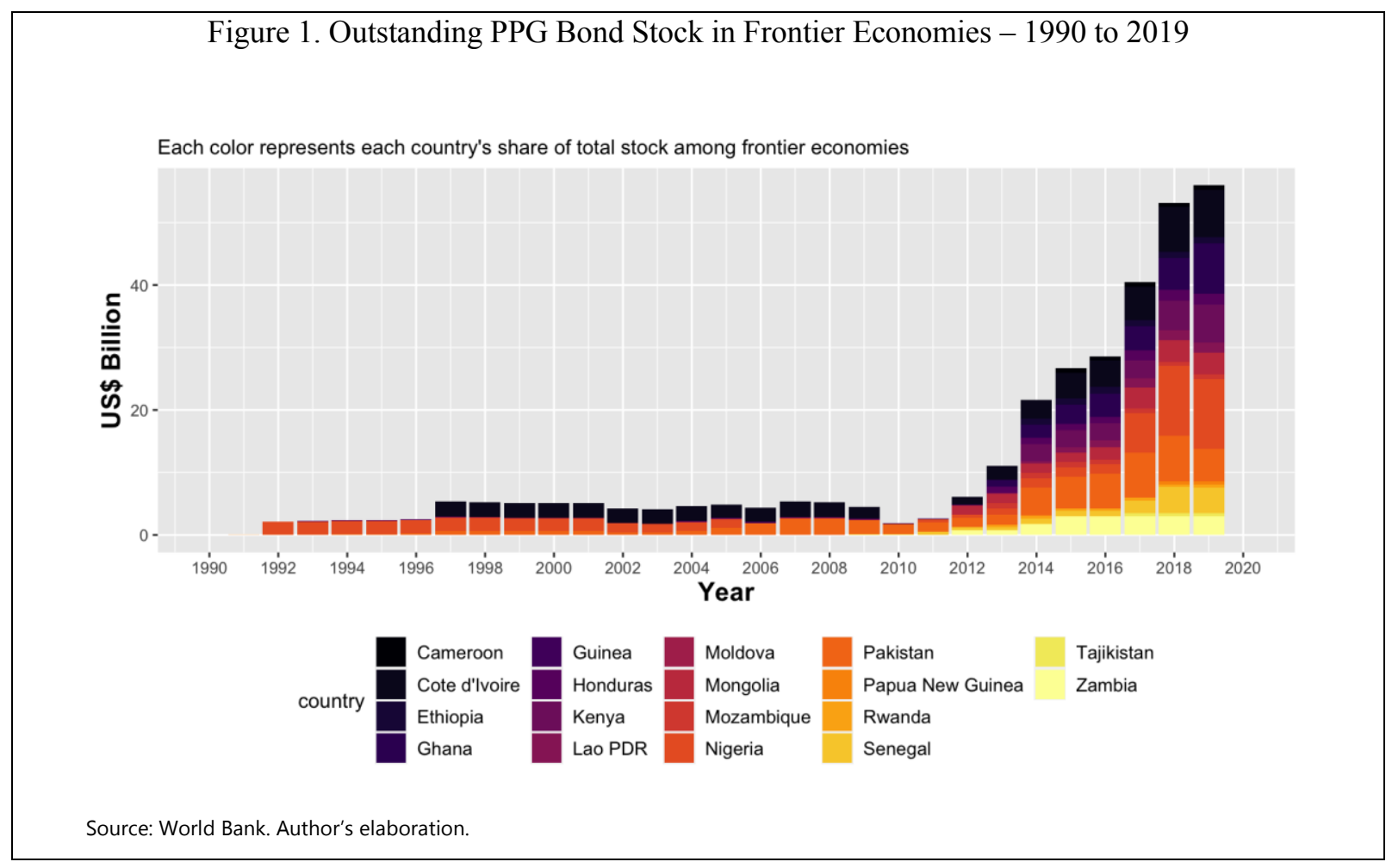

\footnotetext{
${ }^{7}$ US S\&P500 volatility, measured by the Chicago Board Options Exchange Volatility Index (CBOE VIX).

${ }^{8}$ These numbers pertain to the 18 frontier economies included in our sample.
} 
Not only did the volume of issuance increase in the post-GFC period, but there was also an increase in the frequency and the number of issuing countries in our sample (Figure 2). From 1990-2008, there were only 11 international bond issuances by five frontier economies (Pakistan, Moldova, Honduras, Guinea and Mongolia). By contrast, in the decade following 2008, 16 out of 18 frontier economies in our sample were able to tap international capital markets, with 52 bonds issued over this period (Moldova and Guinea were the only exceptions). A median country did not issue in any year during 1990-2008, while issuing in two to three years during 2009-2019. Five countries in our sample (Laos, Senegal, Nigeria, Ghana, and Cote d'Ivoire) issued in at least half of the years between 2009-2019, and African economies accounted for about two-thirds of the issuance over this period. It is worth noting that the lower amount of issuance in 1990-2008 may partly owe to the fact that many countries in our sample were participating in the Heavily Indebted Poor Countries (HIPC) debt relief initiative (launched in 1996) under which they were precluded from issuing market debt until they reached the completion point of the process. By 2009, all but two HIPC countries in our sample had already reached the HIPC completion point. ${ }^{9}$

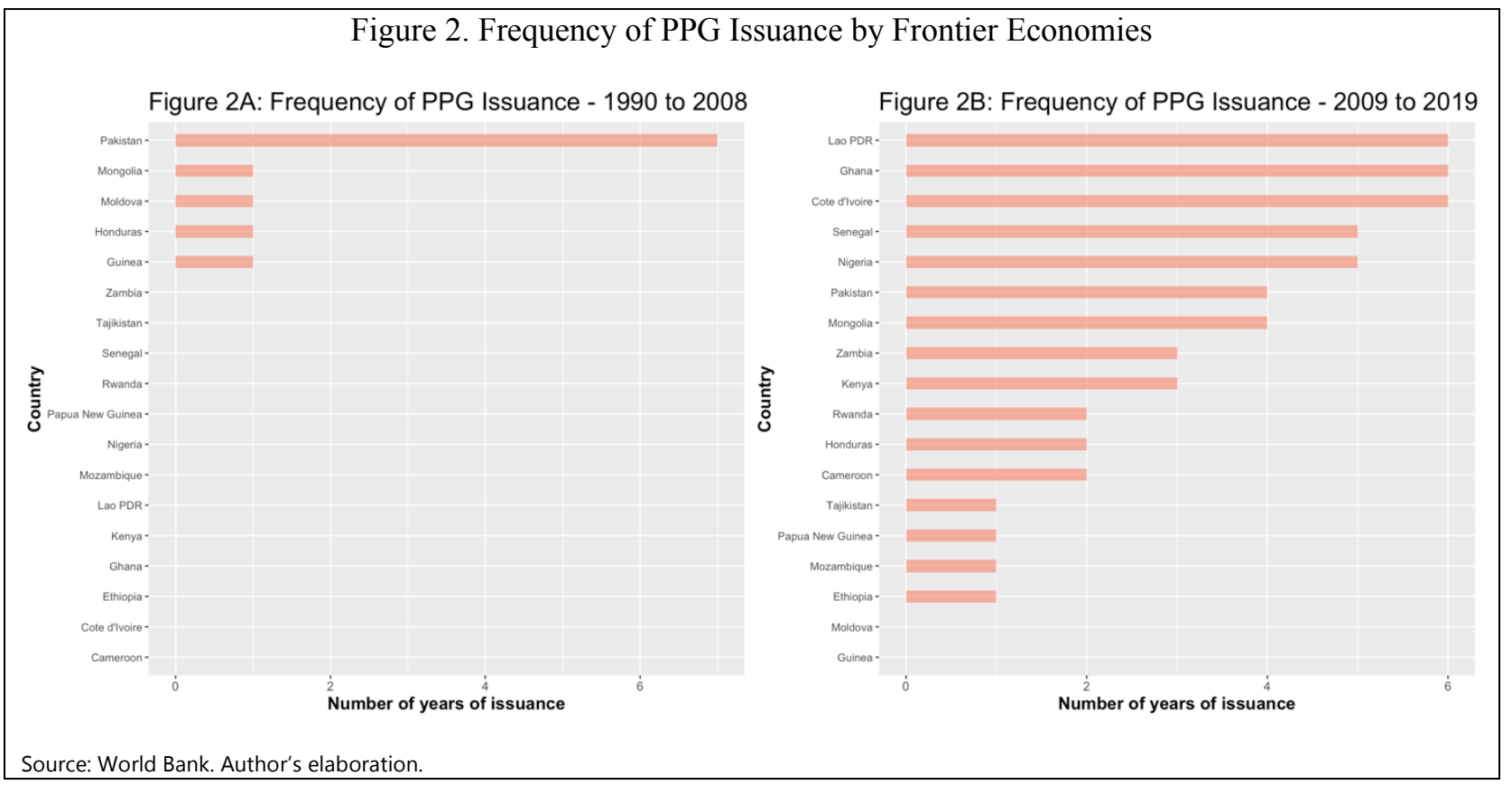

The increase in frontier economies' outstanding PPG bond stock from 2009 also coincided with a decrease in global financial market volatility. Figure 3 shows the evolution of the bond stock in our sample from 2009 to 2019 plotted together with the VIX Index, which represents volatility in global financial markets: it is clear that the increasing slope of the bond stock has corresponded with a decreasing slope for the VIX. This suggests that during calm periods in global financial markets, foreign investors may be less risk averse and therefore more willing to invest in frontier economies.

${ }^{9}$ Guinea and Cote d'Ivoire reached the HIPC completion point in 2012. 


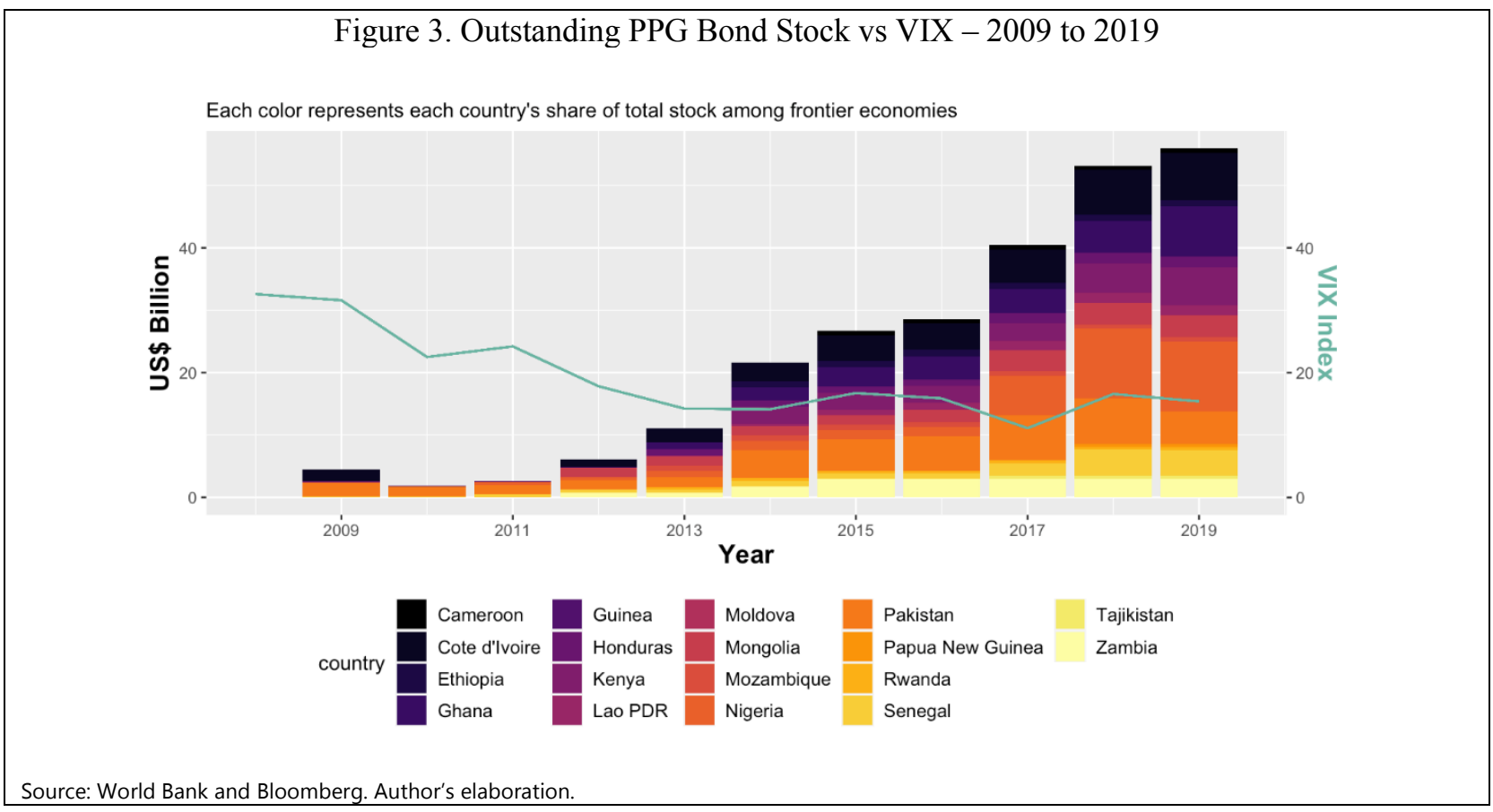

Finally, sovereign spreads to US benchmark Treasuries are a key variable when assessing market access, as they reflect investors' risk assessment of a country and the relative cost of issuing. Figure 4 shows the path of sovereign spreads in our sample using J.P. Morgan's Emerging Market Bond Index Global (EMBI) that tracks the sovereign rates of emerging market countries relative to the US benchmark yield. During the period covered, EMBI spreads have shown a decreasing slope among our pre-selected frontier economies, departing from an average of 1,0002,000 basis points (bps) in the 1990s to around 500 bps after 2009. Since bond yields have an inverse relationship with bond prices, the decrease in spreads indicates an increase in frontier economies' bond prices, which in turn suggests higher demand for their bonds over this period. ${ }^{10}$ The period 2009-19 was also characterized by low yields in advanced economies amid unprecedented amounts of quantitative easing, prompting investors' search for yield in emerging and frontier economies.

\footnotetext{
${ }^{10}$ We note that while the number of frontier economies included in the EMBIG index has increased over time, not all economies in our sample are part of the EMBIG index.
} 
Figure 4. Evolution of EMBIG in Frontier Economies

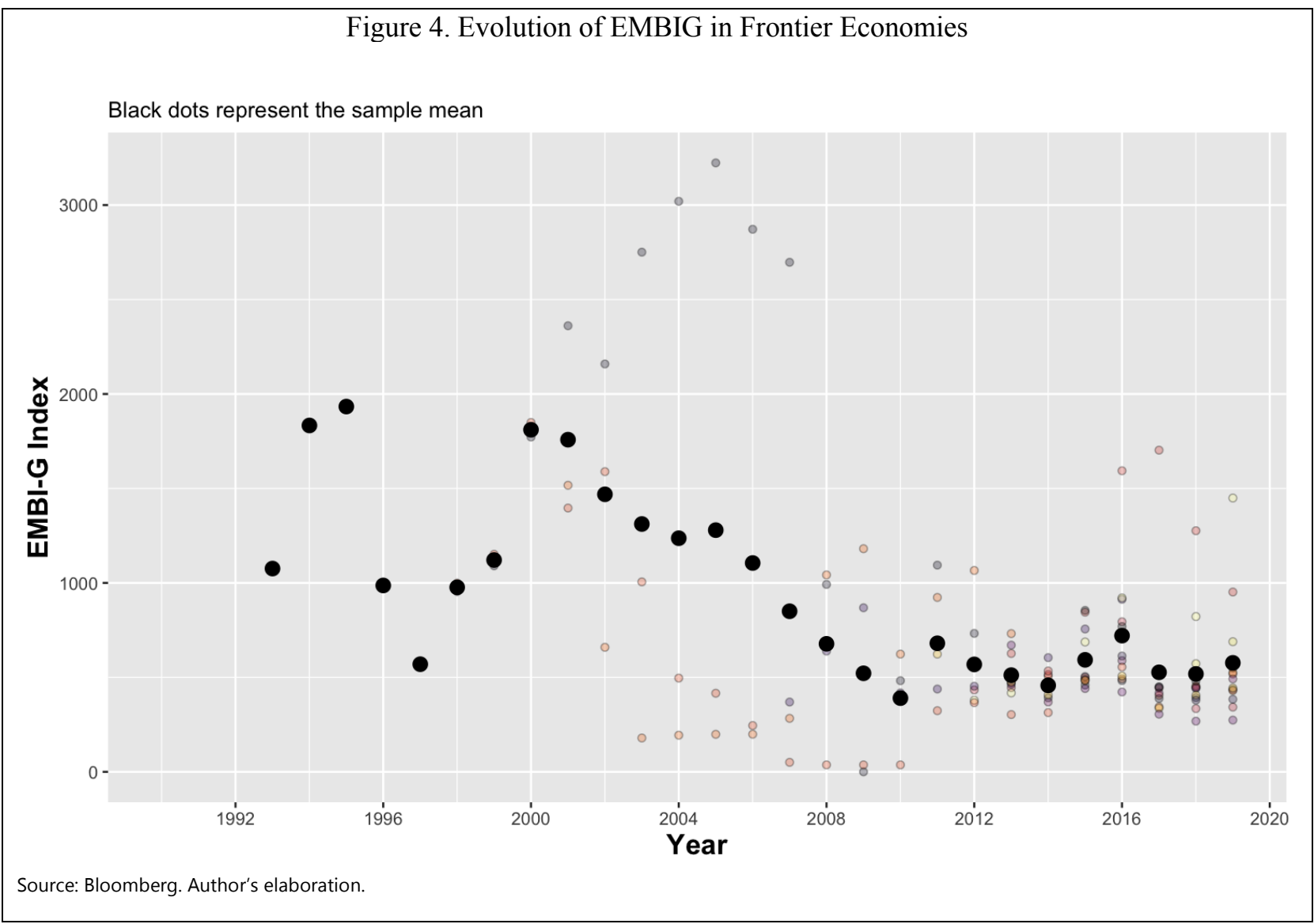

To sum up, our stylized facts show that over the past decade, we have not only seen an increase in PPG bond issuance by frontier economies but also a decrease in their sovereign spreads. Both trends indicate an increase in foreign investors' appetite for frontier economy debt over this period, which has facilitated their increased participation in international capital markets.

\section{EMPIRICAL ANALYSIS}

The empirical section is divided into two parts. In the first section, we use data on frontier economies' external bond issuance and spreads to examine factors that may have contributed to their increased market access in recent years, with the goal of zeroing in on a shortlist of factors or patterns that appear to be most relevant for the assessment of their continued or prospective market access. In the second section, we take a closer look at the predictive power of our probability of issuance model by testing how accurately it would have predicted actual issuance over the past ten years in countries in our sample that have issued at least twice since 1990 (insample prediction).

We use three models in our analysis of the determinants of market access in frontier economies. The first model assesses the linear relationship between the outstanding PPG external bond stock and our set of explanatory variables described above: 


$$
P P G \text { Bond }_{i, t}=\beta_{0}+\beta_{1} \text { Pull }_{i, T}+\beta_{2} \text { Push }_{T}+\alpha_{i}^{i s s}+\delta_{t}^{i s s}+\varepsilon_{i, t}^{i s s}
$$

Where $P P G$ Bond $_{i, t}$ is the outstanding PPG bond stock as a percentage of GDP for each country $i$ and year $t$. $P_{u l l}$ is a set of pull variables for each country $i$ and year $T=\{t-1, t\}$, while $P u s h_{T}$ is a vector of exogenous push factors for each year $T=\{t-1, t\} . \alpha_{i}^{i s s}$ represents potential country fixed effects and $\delta_{t}^{i s s}$ potential time fixed effects. $\varepsilon_{i, t}^{i s s}$ is the error term for each country $i$ and year $t$. We run four identifications for this first regression: a pooled OLS model, a country fixed effects regression, a time fixed effects identification, and finally, an identification that controls for both country and time fixed effects.

Our second model uses the probability of issuance as its dependent variable. The binary variable Issuance $_{i, t}$ is equal to 1 when a given frontier economy $i$ has issued PPG bonds in a given year $t$, and equal to 0 otherwise. Given this definition, we first run three nonlinear identifications-a random effects probit, a random effects logit, and a conditional logit estimation. As the Hausman test rejects the null hypothesis that the country-specific errors are not correlated with the regressors, we also run a linear probability model (LPM) with the same variables, but now accounting for country and time fixed effects. We consider the following model specification:

$$
\operatorname{Prob}\left(\text { Issuance }_{i, t}\right)=\beta_{0}+\beta_{1} \text { Pull }_{i, T}+\beta_{2} \text { Push }_{T}+\varepsilon_{i, t}^{\text {Prob }}
$$

Here, Prob $\left(\right.$ Issuance $_{i, t}$ ) is the probability of PPG bond issuance. We keep the same push and pull variables from Equation (1) and $\varepsilon_{i, t}^{P r o b}$ is the error term. It is worth noting that when an issuance is not observed in this model, it could be a result of a country not having the need to issue or having the need but not finding demand for its bonds. As noted in Presbitero et al (2015), given that frontier economies typically require a large amount of external financing for their investment needs, it is unlikely that there is a lack of need for external financing. However, some economies may opt out of international capital markets due to the availability of grants and concessional loans, or for political reasons. In the absence of a clear identification strategy, the results of this model do not imply causality but rather a correlation.

Our third and final model uses EMBIG spreads as the dependent variable, a proxy for access to international capital markets:

$$
E M B I G_{i, t}=\beta_{0}+\beta_{1} \text { Pull }_{i, T}+\beta_{2} \text { Push }_{T}+\alpha_{i}^{E M B I G}+\delta_{t}^{E M B I G}+\varepsilon_{i, t}^{E M B I G}
$$


With $E M B I G_{i, t}$ being the EMBIG Index representing sovereign spreads for each country $i$ and year t. Pull $l_{i, T}$ and $P u s h_{T}$ are the same vectors of pull and push variables as in Equations (1) and (2). Also, $\alpha_{i}^{E M B I G}$ and $\delta_{t}^{E M B I G}$ are potential country and time fixed effects as in our first model, with $\varepsilon_{i, t}^{E M B I G}$ being the error term. Similar to Equation (1), we look at four different identifications: a pooled OLS model, a country fixed effects regression, a time fixed effects regression, and a country and time fixed effects regression. Country fixed effects capture timeinvariant unobservable country characteristics that may affect countries' propensity to access international capital markets, while time fixed effects capture time-variant global factors common to all countries that may affect their propensity to access international capital markets.

The analyses focus on the period 2009-2019, as it was during this period that international bond issuance by frontier economies started to be observed with more frequency. In order to avoid endogeneity to the extent possible, we have chosen to use lagged explanatory variables, with the exception of the VIX index and EMBI variables that we consider to be fast-moving, as well as the dummy variable for IMF Support. Finally, due to limited data availability, the study uses a dynamic panel data estimation in a case where $\mathrm{T}<\mathrm{N}$, with variables for 18 countries observed over 2009-19. In this sense, the estimation faces a short $\mathrm{T}$ problem that renders the fixed effects estimator biased (the Nickell bias). This bias could potentially be addressed by using the Generalized Method of Moments (GMM) estimation method. ${ }^{11}$

\section{Main results}

The first section of our results explores the interaction between pull and push explanatory variables and our dependent variables representing different gauges of market access, to gain an understanding of what factors may have contributed to frontier economies' bond issuance in the post-GFC decade and could therefore help in the assessment of prospective market access by these economies. The next section takes a closer look at how well our probability model could help with the assessment of prospective market access by testing how accurately the model would have predicted actual issuance over the past decade (in-sample prediction).

\section{A. Determinants of Market Access}

Tables 4, 5, 6 and 7 show the regression results for the three models described above, with the stock of external PPG bonds, probability of issuance, and sovereign spreads serving as proxies for market access, respectively. Given that each of these captures a different element of market access (quantity, timing, price), it is not surprising that the results for pull and push factors' impact on market access vary across the models.

\footnotetext{
${ }^{11}$ As a robustness check, we conducted the analysis for the PPG bond stock regressions using GMM and an Arellano-Bond estimator, but obtained similar results, in terms of both significance and magnitude, to those reported in this paper. Further work on this subject could employ GMM for the probability of issuance and EMBI regressions.
} 
For our first model with outstanding bond stock as the dependent variable (Table 4), the estimated coefficients for most explanatory variables move in the direction we would expect. However, the magnitude and statistical significance of the results varies depending on whether or not we include EMBI spreads as an explanatory variable since data on EMBI spreads is not available for all countries in our sample and therefore their inclusion reduces the sample size. With respect to domestic or 'pull variables', in general, we would expect a larger outstanding bond stock in frontier economies to be associated with sound macroeconomic fundamentals, as these would be more likely to attract higher demand from international investors. In line with this, our results show that a larger outstanding PPG bond stock is positively associated with GDP per capita, GDP growth, private sector credit (a proxy for domestic financial sector development), and rule of law (a proxy for better institutions and governance), and negatively associated with inflation. Results for other macroeconomic fundamentals, while initially less intuitive, make sense when viewed through the lens of countries' financing needs (the bond supply side) rather than investors' demand: a larger PPG bond stock is associated with a lower level of reserves and a higher public debt to GDP ratio, both of which signify higher financing needs for the issuing country. Two variables that do not show statistically significant results are the current account and the IMF support dummy, both of which may owe to a degree of collinearity with other explanatory variables.

The impact of push variables also appears to be relevant to the stock of outstanding PPG bonds. Our analysis suggests that a larger PPG bond stock is associated with lower global market volatility as measured by the VIX index, and with lower EMBI spreads. This is in line with our priors as we would typically expect volatility and spreads to have an inverse relationship with investors' risk appetite and thus to dampen the demand for frontier economy bonds. Finally, US growth, included in our analysis as a proxy for US interest rates to capture investors' chase for yield behavior, shows insignificant results across all specifications, which once again could be a result of collinearity.

Results for our second model, using the probability of issuance as a proxy for market access, are presented in Tables 5 and 6 . This model is not concerned with the volume of bond debt issued by a country but rather the timing of issuance, and allows us to examine whether explanatory variables are positively or negatively associated with bond issuance in any given year. As in our first model, the effects of pull and push variables can be divided into factors associated with the 'demand side' and 'supply side' of frontier economies' bond issuance. The results are similar to those of our first model, but with some interesting exceptions. Taking first our nonlinear specifications (Table 5), we find that the probability of issuance is positively associated with GDP per capita and the rule of law, while being inversely associated with global market volatility and EMBI spreads. In contrast to our first model, however, government debt shows an inverse relationship with the probability of issuance, suggesting that when it comes to the timing of issuance, the financing needs/supply side of the story would be secondary to attracting investor demand through the stronger fundamentals associated with lower public debt to GDP.

The results of our linear probability model (Table 6) confirm the importance of sound fundamentals, indicating a positive association between the probability of issuance and GDP per 
capita, the rule of law, and the current account, while once again showing a negative association with volatility. In line with our first model, they also show an inverse relationship between the probability of issuance and reserves, likely reflecting that higher reserves at any given point in time would reduce the need to issue externally. In contrast to our first model, however, credit to the private sector exhibits an inverse relationship with the probability of issuance in our LPM results, suggesting that the financing needs channel is at play: higher private sector credit to GDP is indicative of a more developed domestic financial market, which in turn may reduce a country's need to issue externally at a given point in time. The economic significance of these coefficients is also non-negligible. For instance: a 10 percent increase in GDP per capita is associated with a 2 percentage point higher likelihood of issuing a bond (column 3 ); an increase in reserves by 1 month of imports is associated with a 12 percentage point decrease in the likelihood of issuing a bond (column 2); and a two-point increase in the VIX index, which is among the $75^{\text {th }}$ percentile of changes in the last 20 years, is associated with a decrease of 5 percentage points in the likelihood of issuing a bond (column 1). It is important to keep in mind that the probability of bond issuance is also influenced by the availability of other sources of financing, such as grants and bilateral loans, which are not included in the model but are partly captured by time fixed effects.

Finally, the results for our third model using EMBI spreads as a proxy for market access are reported in Table 7. As opposed to the previous two specifications, we do not differentiate between supply and demand side factors when interpreting these results. EMBI spreads are themselves a real-time gauge or reflection of the 'cost' of frontier markets' risk and thus 'price in' investors' appetite for frontier markets' bonds - with lower spreads indicating lower perceived risk, and thus a lower cost of issuing. As we would expect, narrower EMBI spreads are related to sounder macroeconomic fundamentals, reflected in higher GDP per capita, higher GDP growth, a higher current account balance, higher reserves, lower public debt, and lower inflation. Narrower spreads are also associated with the presence of an IMF program, which makes sense in the context of frontier economies where IMF programs are often structural in nature and not necessarily triggered by shocks or full-fledged BOP crises. With respect to external 'push factors,' our results depict that higher frontier economies' EMBI spreads are associated with higher global volatility as measured through the VIX, and with higher US interest rates as proxied through higher US growth, both of which we would expect. Finally, the results show a statistically insignificant result for the rule of law, which is somewhat surprising given the positive and significant results we have seen for this variable in our other models. Private credit to GDP also shows an odd positive association with EMBI spreads, although the result is not highly significant from a statistical perspective. 
Table 4: PPG bonds to GDP regressions

\begin{tabular}{|c|c|c|c|c|c|c|c|c|c|}
\hline & & & & & ependent 1 & & & & \\
\hline & & & & & PPG Bond & & & & \\
\hline & & (1) & (2) & (3) & (4) & (5) & (6) & (7) & (8) \\
\hline & $\log (\mathrm{GDPpc})(\mathrm{t}-1)$ & $1.076^{* *}$ & 0.541 & $1.096^{* *}$ & 0.295 & 0.395 & 1.595 & 0.318 & -0.373 \\
\hline & & $(0.516)$ & $(1.544)$ & $(0.503)$ & $(1.981)$ & $(0.363)$ & $(1.094)$ & $(0.364)$ & (1.817) \\
\hline & GDP growth $(\mathrm{t}-1)$ & 0.016 & 0.004 & 0.009 & -0.004 & 0.048 & $0.062^{*}$ & 0.047 & $0.057^{*}$ \\
\hline & & $(0.043)$ & $(0.030)$ & $(0.042)$ & $(0.036)$ & $(0.053)$ & $(0.036)$ & $(0.052)$ & $(0.032)$ \\
\hline & Current Account to GDP (t-1) & -0.004 & -0.027 & -0.015 & -0.026 & 0.015 & -0.004 & 0.011 & -0.003 \\
\hline & & $(0.019)$ & $(0.019)$ & $(0.020)$ & $(0.022)$ & $(0.013)$ & $(0.007)$ & $(0.014)$ & $(0.007)$ \\
\hline & Reserves Assets/Months of Imports (t-1) & -0.037 & $-0.110^{* *}$ & -0.032 & -0.060 & -0.139 & -0.041 & -0.126 & -0.027 \\
\hline & & $(0.150)$ & $(0.051)$ & $(0.110)$ & $(0.097)$ & $(0.090)$ & $(0.052)$ & $(0.080)$ & $(0.054)$ \\
\hline & Government Debt to GDP (t-1) & 0.027 & $0.054^{* * *}$ & 0.013 & $0.051^{* * *}$ & $0.032^{* * *}$ & $0.041^{* * *}$ & $0.028^{* *}$ & $0.039^{* *}$ \\
\hline & & $(0.017)$ & $(0.017)$ & $(0.016)$ & $(0.015)$ & $(0.011)$ & $(0.016)$ & $(0.012)$ & $(0.017)$ \\
\hline & Inflation (t-1) & $-0.095^{* * *}$ & -0.006 & $-0.101^{* *}$ & -0.021 & $-0.044^{*}$ & -0.0004 & $-0.047^{*}$ & -0.018 \\
\hline & & $(0.032)$ & $(0.041)$ & $(0.041)$ & $(0.038)$ & $(0.024)$ & $(0.016)$ & $(0.028)$ & $(0.023)$ \\
\hline & Private Credit to GDP (t-1) & $0.051^{* * *}$ & 0.028 & $0.051^{* * *}$ & 0.030 & $0.043^{* * *}$ & $0.065^{* * *}$ & $0.044^{* * *}$ & $0.071^{* * *}$ \\
\hline & & $(0.020)$ & $(0.042)$ & $(0.019)$ & $(0.041)$ & $(0.013)$ & $(0.017)$ & $(0.013)$ & $(0.017)$ \\
\hline & IMF Support & -0.428 & -0.129 & -0.394 & -0.053 & -0.284 & -0.172 & -0.330 & -0.208 \\
\hline & & $(0.361)$ & $(0.286)$ & $(0.388)$ & $(0.260)$ & $(0.327)$ & $(0.160)$ & $(0.336)$ & $(0.159)$ \\
\hline & Rule of Law (t-1) & $0.032^{* *}$ & $0.122^{* * *}$ & $0.036^{* *}$ & $0.136^{* * *}$ & $0.027^{* * *}$ & $0.047^{* *}$ & $0.027^{* * *}$ & $0.050^{* *}$ \\
\hline & & $(0.015)$ & $(0.035)$ & $(0.015)$ & $(0.031)$ & $(0.009)$ & $(0.018)$ & $(0.008)$ & $(0.020)$ \\
\hline & VIX Index & $-0.041^{*}$ & 0.014 & & & $-0.031^{* *}$ & -0.011 & & \\
\hline & & $(0.022)$ & $(0.022)$ & & & $(0.015)$ & $(0.017)$ & & \\
\hline & US growth (t-1) & 0.021 & -0.023 & & & 0.027 & -0.040 & & \\
\hline & & $(0.067)$ & $(0.132)$ & & & $(0.026)$ & $(0.027)$ & & \\
\hline & EMBI & -0.0003 & $-0.001^{* *}$ & 0.0003 & $-0.001^{*}$ & & & & \\
\hline & & $(0.001)$ & $(0.001)$ & $(0.001)$ & $(0.001)$ & & & & \\
\hline & Constant & -1.152 & & & & -0.889 & & & \\
\hline & & $(1.106)$ & & & & $(0.981)$ & & & \\
\hline Pooling & & Yes & No & No & No & Yes & No & No & No \\
\hline Country FE & & No & Yes & No & Yes & No & Yes & No & Yes \\
\hline Time FE & & No & No & Yes & Yes & No & No & Yes & Yes \\
\hline Observations & & 103 & 103 & 103 & 103 & 183 & 183 & 183 & 183 \\
\hline $\mathrm{R}^{2}$ & & 0.617 & 0.564 & 0.589 & 0.282 & 0.531 & 0.554 & 0.433 & 0.256 \\
\hline Adjusted $\mathrm{R}^{2}$ & & 0.565 & 0.422 & 0.488 & -0.061 & 0.501 & 0.473 & 0.367 & 0.072 \\
\hline
\end{tabular}


Table 5: Probability of Issuance regressions - Non-Linear Marginal Effects

\begin{tabular}{|c|c|c|c|c|c|c|}
\hline & \multicolumn{6}{|c|}{ Dependent variable: } \\
\hline & \multicolumn{6}{|c|}{ Probability of PPG Bond Issuance } \\
\hline & (1) & (2) & (3) & (4) & (5) & (6) \\
\hline \multirow[b]{2}{*}{$\log (\mathrm{GDPpc})(\mathrm{t}-1)$} & $0.241^{*}$ & $0.242 *$ & -0.000289 & $0.240 * *$ & $0.234 * *$ & 0.525 \\
\hline & $(0.102)$ & $(0.102)$ & $(0.00151)$ & $(0.0825)$ & $(0.0821)$ & $(0.702)$ \\
\hline \multirow[b]{2}{*}{ GDP growth (t-1) } & -0.0156 & -0.0174 & -0.0000225 & -0.00250 & -0.00277 & -0.00406 \\
\hline & $(0.0154)$ & $(0.0135)$ & $(0.000142)$ & $(0.00788)$ & $(0.00775)$ & $(0.00764)$ \\
\hline \multirow{2}{*}{ Current Account to GDP (t-1) } & 0.00391 & 0.00261 & 0.0000488 & 0.00428 & 0.00390 & 0.00839 \\
\hline & $(0.0101)$ & $(0.00769)$ & $(0.000311)$ & $(0.00309)$ & $(0.00304)$ & $(0.00751)$ \\
\hline \multirow{2}{*}{ Reserves Assets/Months of Imports (t-1) } & -0.0609 & -0.0631 & -0.000114 & -0.0644 & -0.0660 & -0.0342 \\
\hline & $(0.0426)$ & $(0.0415)$ & $(0.000705)$ & $(0.0360)$ & $(0.0341)$ & $(0.0329)$ \\
\hline \multirow{2}{*}{ Government Debt to GDP (t-1) } & $-0.00599 *$ & $-0.00623 *$ & -0.00000657 & -0.00240 & -0.00257 & -0.00579 \\
\hline & $(0.00288)$ & $(0.00270)$ & $(0.0000452)$ & $(0.00261)$ & $(0.00251)$ & $(0.00687)$ \\
\hline \multirow{2}{*}{ Inflation (t-1) } & -0.0126 & -0.0132 & 0.000000320 & -0.0141 & -0.0141 & -0.00470 \\
\hline & $(0.0104)$ & $(0.0105)$ & $(0.0000232)$ & $(0.00901)$ & $(0.00898)$ & $(0.00550)$ \\
\hline \multirow{2}{*}{ Private Credit to GDP (t-1) } & -0.00463 & -0.00497 & -0.0000502 & -0.00363 & -0.00362 & -0.0109 \\
\hline & $(0.00315)$ & $(0.00305)$ & $(0.000315)$ & $(0.00203)$ & $(0.00201)$ & $(0.00976)$ \\
\hline \multirow[b]{2}{*}{ IMF Support } & -0.0418 & -0.0444 & -0.000169 & -0.0857 & -0.0858 & -0.0312 \\
\hline & $(0.0617)$ & $(0.0643)$ & $(0.00110)$ & $(0.0643)$ & $(0.0627)$ & $(0.0425)$ \\
\hline \multirow{2}{*}{ Rule of Law (t-1) } & $0.00582 * *$ & $0.00588 * *$ & 0.0000317 & $0.00415^{*}$ & $0.00435 *$ & 0.00134 \\
\hline & $(0.00201)$ & $(0.00188)$ & $(0.000205)$ & $(0.00171)$ & $(0.00171)$ & $(0.00359)$ \\
\hline \multirow{2}{*}{ VIX Index } & $-0.0268 *$ & $-0.0267 * *$ & -0.0000273 & -0.0181 & $-0.0172 *$ & -0.0116 \\
\hline & $(0.0106)$ & $(0.00990)$ & $(0.000169)$ & $(0.0103)$ & $(0.00876)$ & $(0.00741)$ \\
\hline \multirow[b]{2}{*}{ US growth (t-1) } & 0.0423 & 0.0441 & 0.0000509 & 0.0159 & 0.0159 & 0.0111 \\
\hline & $(0.0475)$ & $(0.0465)$ & $(0.000329)$ & $(0.0168)$ & $(0.0158)$ & $(0.0118)$ \\
\hline \multirow{2}{*}{ EMBI } & $-0.000403 *$ & $-0.000425^{*}$ & -0.000000537 & & & \\
\hline & $(0.000205)$ & $(0.000201)$ & $(0.00000347)$ & & & \\
\hline RE Logit & Yes & No & No & Yes & No & No \\
\hline RE Probit & No & Yes & No & No & Yes & No \\
\hline Conditional Logit (Country FE) & No & No & Yes & No & No & Yes \\
\hline Observations & 103 & 103 & 102 & 183 & 183 & 165 \\
\hline
\end{tabular}


Table 6: Probability of Issuance regressions - LPM

\begin{tabular}{|c|c|c|c|c|c|c|c|c|}
\hline & \multicolumn{8}{|c|}{ Dependent variable: } \\
\hline & \multicolumn{8}{|c|}{ Probability of PPG Bond Issuance } \\
\hline & (1) & (2) & (3) & (4) & (5) & (6) & (7) & (8) \\
\hline \multirow[b]{2}{*}{$\log (G D P p c)(t-1)$} & 0.192 & 0.00434 & $0.248 * *$ & 1.201 & $0.194^{*}$ & 0.445 & $0.192 *$ & 0.473 \\
\hline & $(0.107)$ & $(0.703)$ & $(0.0934)$ & (1.171) & $(0.0764)$ & $(0.396)$ & $(0.0756)$ & $(0.730)$ \\
\hline \multirow[b]{2}{*}{ GDP growth (t-1) } & -0.0116 & -0.00998 & -0.0110 & -0.00857 & 0.00130 & -0.00623 & 0.00109 & -0.00678 \\
\hline & $(0.0134)$ & $(0.0132)$ & $(0.0119)$ & $(0.0118)$ & $(0.00943)$ & $(0.00901)$ & $(0.00904)$ & $(0.00898)$ \\
\hline \multirow[b]{2}{*}{ Current Account to GDP (t-1) } & 0.00153 & $0.0371 * * *$ & 0.000836 & $0.0380 * *$ & 0.00414 & 0.00657 & 0.00413 & 0.00633 \\
\hline & $(0.00643)$ & $(0.00783)$ & $(0.00645)$ & $(0.0104)$ & $(0.00292)$ & $(0.00359)$ & $(0.00297)$ & $(0.00356)$ \\
\hline \multirow{2}{*}{ Reserves Assets/Months of Imports (t-1) } & -0.0448 & $-0.121 *$ & -0.0286 & -0.0646 & $-0.0641 *$ & $-0.0902 *$ & -0.0545 & $-0.0792 *$ \\
\hline & $(0.0396)$ & $(0.0558)$ & $(0.0442)$ & $(0.0667)$ & $(0.0295)$ & $(0.0321)$ & $(0.0307)$ & $(0.0342)$ \\
\hline \multirow{2}{*}{ Government Debt to GDP (t-1) } & -0.00382 & -0.00692 & -0.00296 & -0.00602 & -0.000532 & -0.00543 & -0.000104 & -0.00459 \\
\hline & $(0.00234)$ & $(0.00573)$ & $(0.00289)$ & $(0.00751)$ & $(0.00204)$ & $(0.00457)$ & $(0.00220)$ & $(0.00452)$ \\
\hline \multirow{2}{*}{ Inflation (t-1) } & -0.00980 & -0.000582 & -0.0134 & -0.00823 & -0.00786 & 0.000877 & -0.00923 & -0.0000212 \\
\hline & $(0.0114)$ & $(0.0168)$ & $(0.0105)$ & $(0.0176)$ & $(0.00675)$ & $(0.00686)$ & $(0.00770)$ & $(0.00943)$ \\
\hline \multirow[b]{2}{*}{ Private Credit to GDP (t-1) } & -0.00425 & $-0.0337^{*}$ & -0.00559 & $-0.0503 *$ & -0.00279 & -0.00822 & -0.00316 & -0.00891 \\
\hline & $(0.00341)$ & $(0.0153)$ & $(0.00323)$ & $(0.0195)$ & $(0.00209)$ & $(0.00632)$ & $(0.00216)$ & $(0.00730)$ \\
\hline \multirow[b]{2}{*}{ IMF Support } & -0.0343 & -0.0636 & -0.0187 & -0.00766 & -0.0909 & -0.0756 & -0.0760 & -0.0519 \\
\hline & $(0.0778)$ & $(0.128)$ & $(0.0788)$ & $(0.131)$ & $(0.0705)$ & $(0.0710)$ & $(0.0683)$ & $(0.0678)$ \\
\hline \multirow[b]{2}{*}{ Rule of Law (t-1) } & $0.00401 *$ & $0.0304 *$ & $0.00397 *$ & $0.0401 *$ & $0.00393 *$ & 0.00779 & $0.00408 *$ & 0.0100 \\
\hline & $(0.00158)$ & $(0.0108)$ & $(0.00168)$ & $(0.0151)$ & (0.00199) & $(0.00816)$ & $(0.00197)$ & $(0.00857)$ \\
\hline VIX Index & $\begin{array}{c}-0.0259 * * * \\
(0.00769)\end{array}$ & $\begin{array}{l}-0.0261 * \\
(0.0118)\end{array}$ & & & $\begin{array}{l}-0.0124 * \\
(0.00539)\end{array}$ & $\begin{array}{l}-0.0176^{*} \\
(0.00635)\end{array}$ & & \\
\hline US growth (t-1) & $\begin{array}{c}0.0116 \\
(0.0413)\end{array}$ & $\begin{array}{l}-0.0141 \\
(0.0476)\end{array}$ & & & $\begin{array}{l}0.00240 \\
(0.0117)\end{array}$ & $\begin{array}{l}0.00202 \\
(0.0120)\end{array}$ & & \\
\hline EMBI & $\begin{array}{l}-0.000126 \\
(0.000190)\end{array}$ & $\begin{array}{r}-0.0000645 \\
(0.000194)\end{array}$ & $\begin{array}{l}-0.0000553 \\
(0.000169)\end{array}$ & $\begin{array}{c}0.000192 \\
(0.000192)\end{array}$ & & & & \\
\hline Constant & $\begin{array}{c}1.090 * * * \\
(0.274)\end{array}$ & & & & $\begin{array}{c}0.593 * * * \\
(0.176)\end{array}$ & & & \\
\hline Pooling & Yes & No & No & No & Yes & No & No & No \\
\hline Country FE & No & Yes & No & Yes & No & Yes & No & Yes \\
\hline Time FE & No & No & Yes & Yes & No & No & Yes & Yes \\
\hline Observations & 103 & 103 & 103 & 103 & 183 & 183 & 183 & 183 \\
\hline
\end{tabular}


Table 7: EMBIG regressions

\begin{tabular}{|c|c|c|c|c|}
\hline & \multicolumn{4}{|c|}{ Dependent variable: } \\
\hline & \multicolumn{4}{|c|}{ EMBIG Index } \\
\hline & (1) & $(2)$ & (3) & (4) \\
\hline \multirow[t]{2}{*}{$\log (\mathrm{GDPpc})(\mathrm{t}-1)$} & -60.743 & $-1,079.748^{* * *}$ & -47.778 & $-997.252^{* * *}$ \\
\hline & $(74.991)$ & $(200.910)$ & $(73.582)$ & $(347.839)$ \\
\hline \multirow[t]{2}{*}{ GDP growth $(\mathrm{t}-1)$} & $-24.912^{* * *}$ & -10.951 & $-22.430^{* *}$ & -9.278 \\
\hline & $(9.653)$ & $(7.521)$ & $(9.632)$ & $(7.533)$ \\
\hline \multirow[t]{2}{*}{ Current Account to GDP (t-1) } & $-8.472^{* *}$ & -5.342 & $-7.691^{* *}$ & $-6.380^{* *}$ \\
\hline & $(4.072)$ & $(3.824)$ & $(3.634)$ & $(3.148)$ \\
\hline \multirow[t]{2}{*}{ Reserves Assets/Months of Imports (t-1) } & $-41.622^{*}$ & $-64.116^{* * *}$ & $-43.008^{* *}$ & $-82.952^{* * *}$ \\
\hline & $(23.312)$ & $(20.049)$ & $(21.744)$ & $(24.900)$ \\
\hline \multirow[t]{2}{*}{ Government Debt to GDP (t-1) } & $4.249^{* *}$ & $8.978^{* * *}$ & $5.543^{* * *}$ & $8.615^{* * *}$ \\
\hline & $(1.825)$ & $(2.867)$ & $(1.964)$ & $(2.476)$ \\
\hline \multirow[t]{2}{*}{ Inflation $(\mathrm{t}-1)$} & 11.263 & $18.657^{* * *}$ & $10.742^{*}$ & $19.667^{* * *}$ \\
\hline & $(7.117)$ & $(7.100)$ & $(6.373)$ & $(5.289)$ \\
\hline \multirow[t]{2}{*}{ Private Credit to GDP (t-1) } & -2.440 & $16.340^{*}$ & -2.490 & $18.501^{*}$ \\
\hline & $(2.095)$ & $(8.449)$ & $(2.098)$ & $(9.485)$ \\
\hline \multirow[t]{2}{*}{ IMF Support } & -28.936 & $-91.284^{*}$ & -31.105 & $-101.355^{* *}$ \\
\hline & $(52.283)$ & $(48.889)$ & $(46.296)$ & $(40.278)$ \\
\hline \multirow[t]{2}{*}{ Rule of Law (t-1) } & -1.474 & 1.348 & -2.043 & -1.529 \\
\hline & $(1.079)$ & $(4.280)$ & $(1.294)$ & $(3.079)$ \\
\hline \multirow[t]{2}{*}{ VIX Index } & $15.149^{* *}$ & 3.226 & & \\
\hline & $(7.206)$ & (7.103) & & \\
\hline \multirow[t]{2}{*}{ US growth (t-1) } & $56.109^{* * *}$ & $95.738^{* * *}$ & & \\
\hline & $(12.633)$ & $(15.339)$ & & \\
\hline \multirow[t]{2}{*}{ Constant } & $355.796^{* *}$ & & & \\
\hline & $(165.779)$ & & & \\
\hline Pooling & Yes & No & No & No \\
\hline Country FE & No & Yes & No & Yes \\
\hline Time FE & No & No & Yes & Yes \\
\hline Observations & 99 & 99 & 99 & 99 \\
\hline $\mathrm{R}^{2}$ & 0.522 & 0.494 & 0.550 & 0.495 \\
\hline Adjusted $\mathrm{R}^{2}$ & 0.462 & 0.348 & 0.441 & 0.273 \\
\hline
\end{tabular}




\section{B. Prospective Market Access}

Assessing countries' prospective access to international debt markets primarily relates to assessing investors' appetite for holding their bonds. In the context of frontier economies, which are the newest entrants to the global sovereign debt arena, having successfully issued an external bond once may not necessarily signify perennial access to international markets, particularly when political or economic circumstances in the issuing country change. So how do we gauge whether a frontier economy would find demand for its bonds in international capital markets in the future if the need arose? The analysis on the determinants of market access in the previous subsection provides valuable information on factors affecting investors' demand for frontier economies' bonds. The analysis also demonstrates that EMBI spreads themselves represent a useful embodiment of the risk associated with investing in a country's bonds as well as global risk appetite, with narrower spreads reflecting lower risk and thereby potentially greater demand that would allow the placement of bonds at financially viable yields. The first two models of our determinants of market access analysis used countries' outstanding stock of bonds relative to GDP, and the probability of issuing a bond in a given year as dependent variables representing market access. In this section, we take a closer look at how well our probability of issuance model captures market access at a given point in time by testing how accurately the model would have predicted actual issuance over the past eleven years (2009-2019) by countries in our sample.

Specifically, we predict the in-sample probability that a frontier economy has issued PPG bonds in a given year by computing the fitted values for both our nonlinear and linear probability models. We then analyze how each model performs by calculating the percentage of "correct predictions" when measured against the observed issuances in actual data. In testing our models this way, from our original sample of 18 frontier economies, we only keep 12 that have issued PPG bonds at least twice during the period from 1990 to 2019, with at least one issuance occurring between 2009-19, in order to ensure that our models' predictive power is only being gauged on countries that already have the apparatus in place to issue bonds. Figure 5 shows the number of issuances by these 12 economies in 2009-19. ${ }^{12}$

We use the following methodology to calculate the effectiveness of our models. Model predictions are considered to be correct if: (i) the fitted probability of issuance prediction for a given year and country is greater than or equal to 0.5 and this country has actually issued PPG bonds in that year, or (ii) the fitted probability of issuance prediction for a given year and country is lower than 0.5 and this country has actually not issued in that year. Given this definition, we define the indicator percentage of correct predictions as:

$$
\% \text { Correct Predictions }=\frac{\text { Amount of Correct Predictions }}{\text { Amount of Total Predictions }}
$$

\footnotetext{
${ }^{12}$ Cameroon, Côte d'Ivoire, Ghana, Honduras, Kenya, Lao PDR, Mongolia, Nigeria, Pakistan, Rwanda, Senegal and Zambia.
} 
Figure 5. Number of issuances by year and country

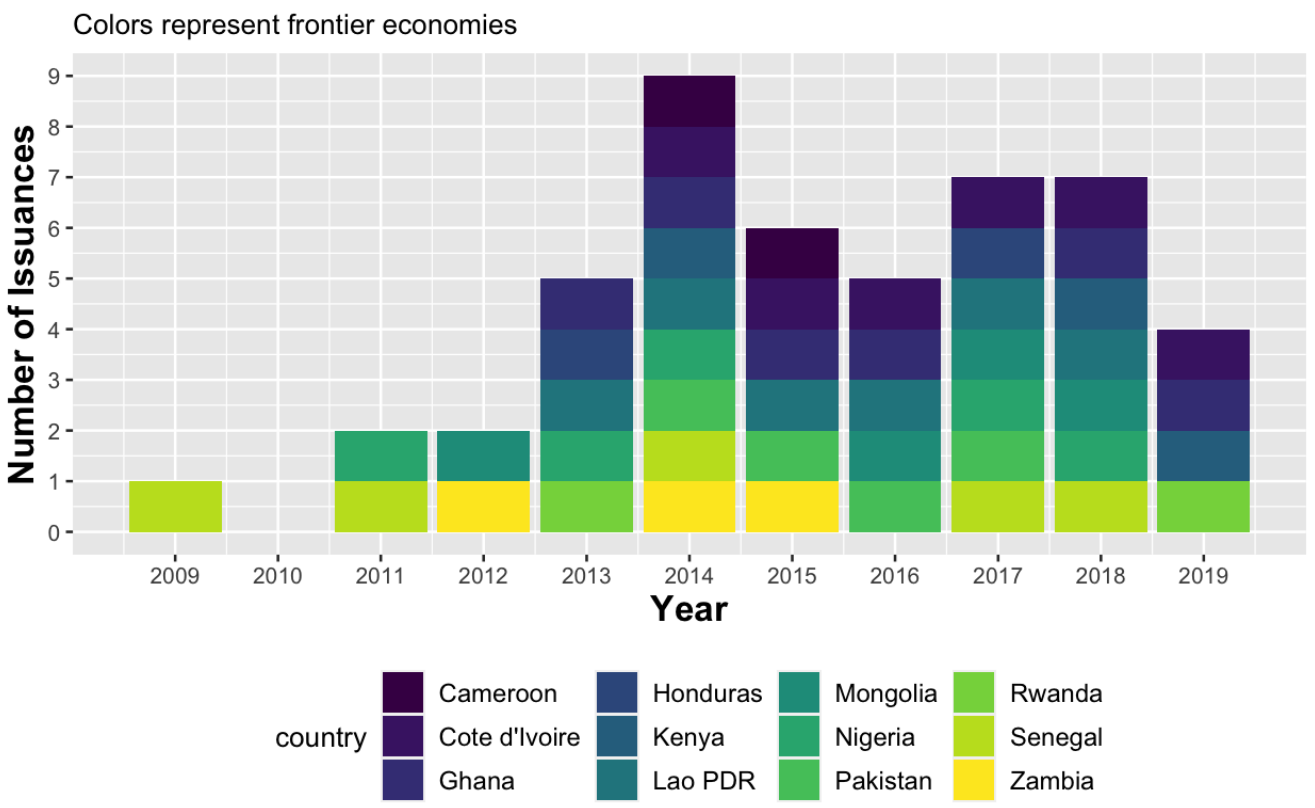

Source: World Bank. Authors' elaboration

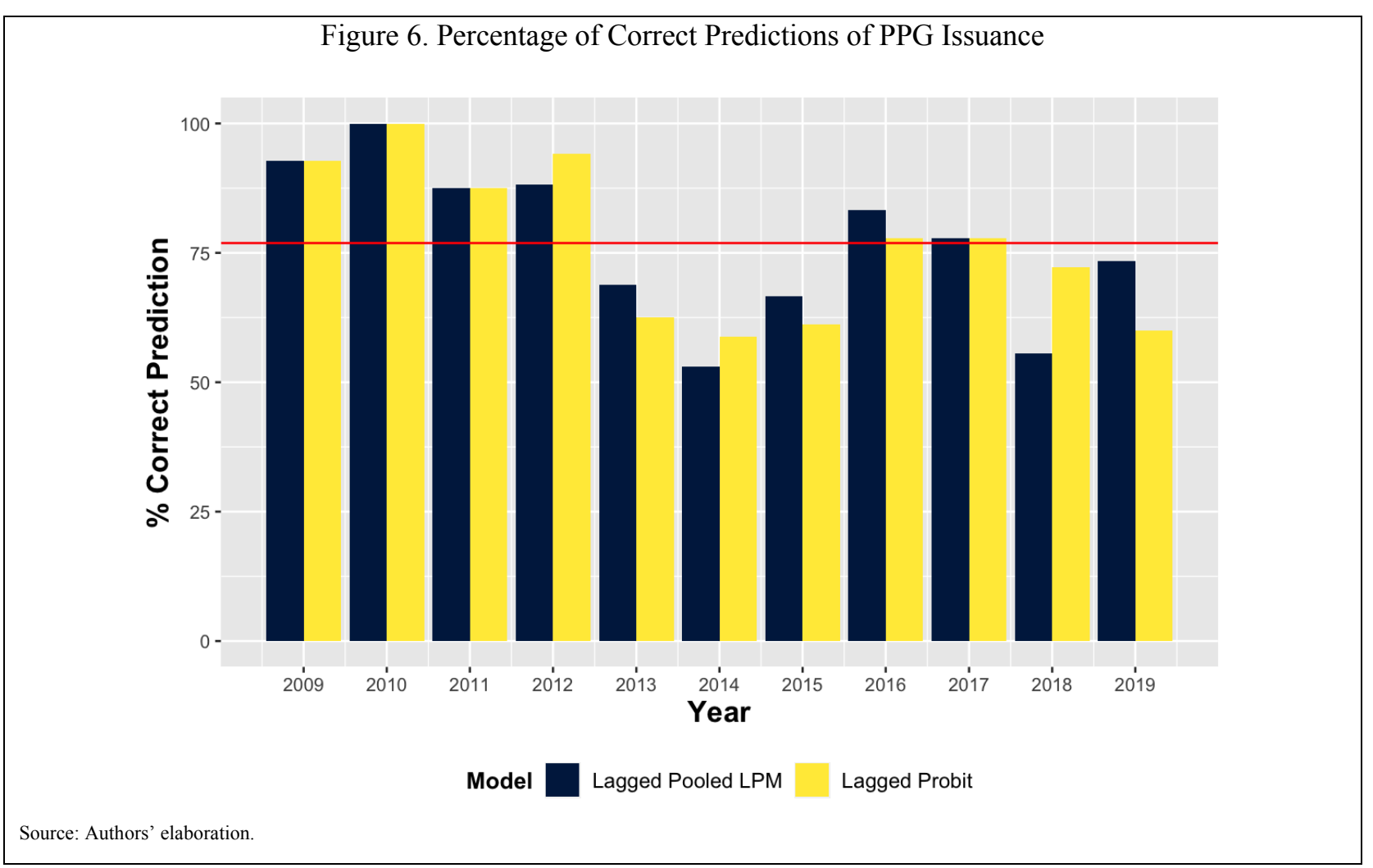


Figure 6 shows the evolution of correct predictions for the two best-performing models out of our various nonlinear and linear specifications: the pooled LPM and Probit model. The two models show an average percentage of correct predictions between 2009-19 of about 75 percent.

The fitted values predicted by our pooled LPM and Probit models together with actual issuances for each country are shown in Figure 7. If we focus more narrowly on the years 2013-19, as 90 percent of total issuances between 2009-19 occurred during these years, we find that while both models seem to capture the correct overall trend for most countries, for some countries such as Honduras, Kenya and Nigeria, the link between the model predictions and actual data is not easily discernible. Indeed, the average percentage of correct predictions for the models falls to about 67.8 percent for this sub-period. Moreover, while we include the most obvious pull and push factors in our models, neither model accounts for political events or other country-specific shocks, or cyclical events such as commodity price shocks. This clearly impacts the predictive power of the models: for example, 2014 was the year of lowest correct predictions for both models (Figure 6); this was also the year of maximum number of issuances between 2009-19 (Figure 5) and marked the end of the so-called "commodity price boom" with a major reversal in commodity prices, a shock that was not captured by the models. Indeed, when we run the models with the Bloomberg Commodities Index included as an explanatory variable, this materially improves the percentage of correct predictions in 2014. Nonetheless, if the models were to be used to help assess prospective market access for a particular frontier economy at a particular point in time, it would be possible to control for some of these shocks.

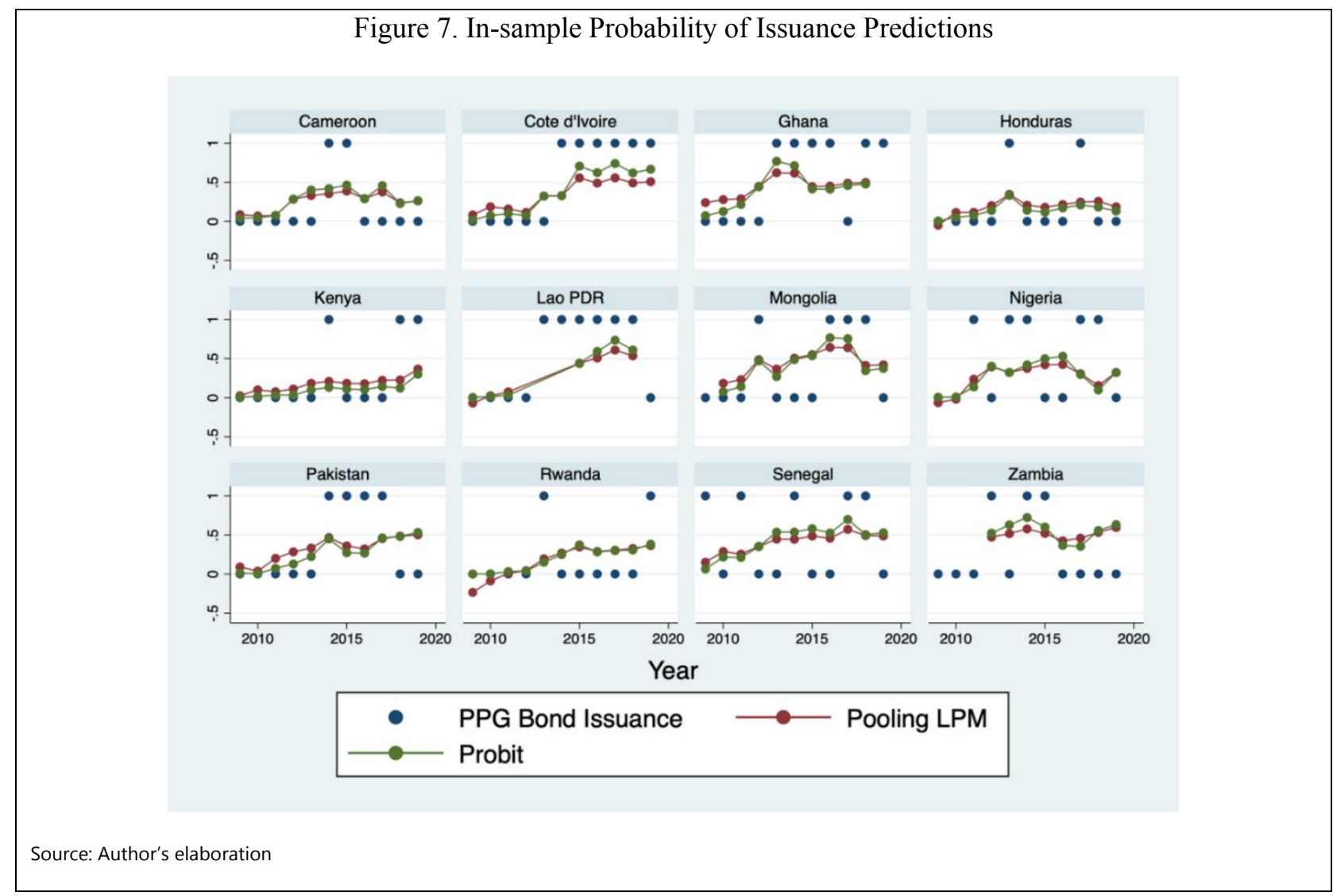


In summary, the results of our analysis on factors affecting frontier economies' market access vary depending on which measure of market access we choose. However, there are still several general conclusions that hold true. First, both pull and push factors seem to be relevant for frontier economies' recent surge in access to international capital markets. Second, the impact of some domestic 'pull' factors can be more related to the demand side, capturing investors' appetite for frontier economies' debt, or to the supply of bonds, reflecting frontier economies' financing needs, depending on which aspect of market access our dependent variable represents. The outstanding stock of bond debt, for instance, seems to relate to both investors' demand for bonds and frontier economies' financing needs as it reflects the overall volume of issuance over time, while the probability of issuance and EMBI spreads - reflecting the timing and cost of issuance, respectively — not surprisingly seem to be more influenced by investors' demand. The credit to the private sector variable displays a particularly interesting result, with a positive association to the outstanding bond stock on the one hand, and an inverse association to the probability of issuance on the other. While seemingly contradictory, both results are intuitive as a deeper, more developed domestic financial sector would be more likely to attract a larger stock of external bonds, while at the same time potentially reducing the need to issue externally at a point in time given domestic financing options. Box II summarizes how our results for frontier economies compare to the results of previous studies on emerging markets.

Finally, we test the predictive power of our probability of issuance model by examining how accurately the model would have predicted actual issuance over the past eleven years (20092019) for a subset of countries in our sample that issued bonds at least twice in the 1990-2019 period, with at least one of those issuances occurring in 2009-19. Our results indicate that the Probit and pooled LPM specifications work best. While their average percentage of correct predictions during the 2013-19 period (when most issuances occurred) is 67.8 percent, the sample size and timeframe are still too small and short to come to a definitive conclusion. Nonetheless, these models could certainly provide a useful input to an assessment of a frontier economy's prospective market access. 


\section{Box II. Effects of Pull and Push Factors on Market Access in Emerging Economies}

The analysis in this paper examines factors affecting market access in a specific group of low-income countries (LICs) that we refer to as frontier economies. While comparable analysis on these economies is sparse given their relatively recent entry into international financial markets, the literature is rich with similar analyses for emerging economies. As highlighted in Section II, Comelli et al (2012) analyze the effects of both pull and push factors on sovereign bond spreads of 28 emerging economies between 1998 and 2011, while Presbitero et al (2015) study the ability of 48 Emerging Market and Developing Economies (EMDEs) to issue bonds in international markets.

The proxies for market access and explanatory variables used in our paper are similar to the specifications in Comelli et al (2012) and Presbitero et al (2015). Our results are in line with their results for emerging markets, which also find that macroeconomic fundamentals as well as external conditions matter for market access. Specifically, sound macroeconomic fundamentals and more favorable external conditions - as reflected through a lower VIX index - are associated with a higher probability of issuance. In addition, Presbitero et al (2015) also find a negative relationship between the level of reserves and the probability of issuing, reflecting countries' financing needs rather than their fundamentals. Finally, like Comelli (2012) and Presbitero (2015), we find a negative relationship between the US interest rate and market access in emerging markets in our robustness analysis using 10 -year treasury rates.

However, in a few aspects, our results differ from these previous studies. First, as opposed to Presbitero et al (2015), inflation has both statistical and economic significance in our regression on sovereign spreads, with higher inflation linked to higher spreads. Second, Presbitero et al (2015) find robust evidence for catalytic effects from IMF support on emerging markets' odds of issuing a bond, while we find the opposite in our robustness analysis, and statistically insignificant results in our main odds of issuance analysis. Table 8 summarizes the impact of key variables on market access in these papers and ours.

\begin{tabular}{|c|c|c|c|c|c|c|}
\hline \multicolumn{7}{|c|}{ Table 8. Factors Affecting Market Access in EE vs Frontier Economies 1/ } \\
\hline & \multicolumn{7}{|c|}{ Pull Factors } & \multicolumn{2}{c|}{ Push Factors } \\
\cline { 2 - 7 } & $\begin{array}{c}\text { Reserve } \\
\text { Assets }\end{array}$ & IMF Support & Inflation & $\begin{array}{c}\text { Other } \\
\text { Macroeconomic } \\
\text { Fundamentals }\end{array}$ & $\begin{array}{c}\text { US interest } \\
\text { rates/growth }\end{array}$ & VIX \\
\hline Presbitero et al (2015) & $\downarrow$ & $-\uparrow$ & - & $\uparrow$ & $\downarrow$ & $\downarrow$ \\
\hline Comelli (2012) & - & - & - & $\uparrow$ & $\downarrow$ & $\downarrow$ \\
\hline This paper & $\downarrow$ & $\downarrow$ & $\downarrow$ & & $\downarrow$ \\
\hline $1 /$ "-" is used to depict statistically insignificant results.
\end{tabular}

\section{Robustness Analysis}

\section{US 10-year bond yield as a proxy for US interest rates}

In our main regressions, we opted for using US growth instead of the US policy rate or 10-year bond yield in order to assess whether the 'investors' chase for yield' theory holds true (on the assumption that US growth and interest rates are positively correlated). The reason for this was two-fold: in the period under analysis (2009-2019) US reference rates have been at historically low levels, and US growth also reflects the benefits of investing in the US. It is important to note, however, that the US neutral rate of interest has been declining and this may affect the 
relationship between the neutral rate and US growth (although we would not expect it to change the direction of the relationship). Moreover, the link between short- and long-term rates has been non-monotonic over the years, with the yield curve even inverting periodically. Appendix 2 shows that if we replace US growth by US 10-year yields, the latter is only significant for our first model with outstanding bond stock as the dependent variable, and exhibits a negative sign, indicating that higher US bond yields are associated with a lower bond stock in frontier economies. This is an intuitive result, consistent with the argument that higher interest rates in the US would reduce investors' incentive to chase higher yields in riskier frontier economies.

\section{Different IMF concessional (PRGT) facilities}

In our main regressions, only our third model with EMBI spreads as the dependent variable displayed statistically significant results for the IMF Support dummy variable, indicating an inverse relationship between IMF support and spreads. However, the IMF Support variable in our main regressions does not differentiate between different types of PRGT financing arrangements. This robustness check investigates whether we get different results if we replace the IMF financial support dummy by an Extended Credit Facility (ECF) dummy and a Standby Credit Facility (SCF) dummy. The ECF is a medium-to-long-term arrangement that caters to protracted and structural BoP problems in LICs, while the SCF is a facility for LICs with actual or potential short-term BoP problems (typically caused by a shock). For each arrangement, we build a dummy that is equal to 1 if a frontier economy has received ECF/SCF support in a given year and equal to zero otherwise. Appendix 3 shows that both SCF and ECF financing are related to a lower probability of issuance, which is plausible since IMF financing would likely preclude the need to issue bonds. In addition, the SCF is related to a lower outstanding bond stock. And finally, in line with our main results, ECF support is associated with lower EMBI spreads.

\section{Country fundamentals in times of global turmoil}

Our results indicate that global market volatility is negatively correlated with frontier economies' market access, while sound macroeconomic fundamentals show a positive correlation with access. In order to check whether stronger country-specific macroeconomic fundamentals can improve the likelihood of issuance at times of global turmoil, i.e., whether investors still differentiate across countries based on fundamentals at such times, we add an interaction between the VIX index and the rule of law to our regression specifications. The results in Appendix 4 show that this is not the case; i.e., good institutions matter less for market access amidst global financial turmoil. This implies that solid macroeconomic fundamentals do not necessarily help frontier economies to access international capital markets in times of global crises, as investors' risk appetite is typically very low and there is a flight to safety.

\section{Commodity prices}

Several countries in our sample are rich in natural resources, with commodities accounting for a significant share of their exports. Furthermore, when testing the predictive power of our probability models, we found that including the Bloomberg Commodities Index (BCOM) as an independent variable materially improved the percentage of correct predictions for the 
probability of issuance in 2014, a year when commodity-exporting economies were affected by a major negative reversal in commodity prices. A robustness check to investigate the impact of commodity prices on our results therefore seems warranted. Appendix 5 shows that our main results are largely robust to inclusion of the BCOM Index (in level terms). The index shows a significant and inverse correlation with market access as measured by the PPG bond stock, but a positive correlation with the probability of issuance in our nonlinear model, suggesting that it impacts the former from the financing needs or supply side, and the latter from the demand side.

\section{Conclusion}

This paper investigates factors that may have contributed to the increased access to international capital markets enjoyed by a group of higher-income LICs that we call frontier economies over the past decade. Using data on external bond issuance and sovereign spreads, we find that both domestic macroeconomic fundamentals as well as external conditions have played a role in frontier economies' increased access to capital markets. However, results vary depending on the measure of market access used for our dependent variables, and the channel through which explanatory variables affect our dependent variables.

While some domestic fundamentals or 'pull factors', such as the level of reserves, operate more through their impact on frontier economies' external financing needs (the bond supply side), others, such as GDP per capita, GDP growth, the current account, and rule of law are primarily relevant through their impact on investors' demand for frontier economies' bonds. In particular, the outstanding external bond stock, a proxy for total volume of issuance over time, relates to both investors' demand for bonds and frontier economies' financing needs, while the probability of issuance and EMBI spreads - reflecting the timing and cost of issuance, respectivelyrespond more to investors' demand for bonds. The level of development of frontier economies' domestic financial markets, proxied through private credit-to-GDP, plays an interesting role in our analysis: on the one hand, this variable positively correlates to market access over time, reflecting countries' higher capacity to issue internationally and lower repayment risks; on the other, deeper domestic financial markets help preclude the need to issue externally at a given point in time on account of greater domestic financing options.

With respect to external factors, higher global market volatility, which typically coincides with lower global risk appetite, is associated with lower bond stocks and probability of issuance, and higher EMBI spreads, as would be expected. As for US interest rates, proxied through US growth, while we find only indirect evidence for a 'chase for yield' argument through a positive association with EMBI spreads in our main regressions, we find firmer evidence in our robustness analysis, when we replace US growth with US 10-year yields, suggesting that higher bond yields in advanced economies tend to reduce investors' interest in riskier frontier markets. Finally, the results of our robustness analysis suggest that the importance of domestic macroeconomic fundamentals in frontier economies recedes at times of global financial turmoil as investors' risk appetite falls and there is a flight to safety. 
The results of our analysis on factors related to frontier economies' increased market access provide useful information for the assessment of their prospective access to international markets. To test this, we assess the predictive power of our probability of issuance model by examining how accurately the model would have predicted actual issuance over the past eleven years (2009-2019) for a subset of countries in our sample. We find that the Probit and pooled LPM specifications work best, showing an average percentage of correct predictions over this period of about 77 percent. While a longer time period and larger sample would be needed to more definitively assess the model's effectiveness, it can certainly be used as an additional input when judging frontier economies' prospective market access, which is an important consideration in the IMF's concessional lending framework.

Looking ahead, further research would clearly entail extending the timeframe covered as more data becomes available, and would also need to take into account the impact of the COVID-19 pandemic on frontier economies' market access. When feasible, it would be useful to test the predictive power of our probability model with an out-of-sample analysis. Application of machine learning techniques would allow us to infer causality rather than correlation in our variables: one option would be the machine learning framework proposed by Athey and Imbens (2015) and Davis and Heller (2017), where they implement a causal forest algorithm to estimate heterogeneity in causal effects. Finally, it is important to note that while gaining access to international markets brings various benefits for frontier economies, external bond issuance also entails the assumption of exchange rate and other risks by the issuing governments and must therefore be carefully managed. Indeed, some of these vulnerabilities have been exposed by the adverse impact of the unprecedented COVID-19 shock on debt dynamics and sustainability in frontier economies and emerging markets. 


\section{REFERENCES}

Athey, S. and Imbens, G., 2015. "Machine Learning Methods for Estimating Heterogeneous Causal Effects". REPEC Research Papers.

Berger, D., Pukthuanthong, K., \& Yang, J., 2011. "International Diversification with Frontier Markets”. Journal of Financial Economics, 227-242.

Comelli, F., 2012. "Emerging Market Sovereign Bond Spreads: Estimation and Back-testing”. IMF Working Paper No 212.

Corsetti, G., Guimarães, B., and Roubini, N. 2006. "International Lending of Last Resort and Moral Hazard: A model of IMF's catalytic finance”. Journal of Monetary Economics, 441-471.

Croissant, Y. and Millo, G. 2019. "Panel Data Econometrics with R”. John Wiley \& Sons Ltd.

Davis, Jonathan M.V., and Sara B. Heller. 2017. "Using Causal Forests to Predict Treatment Heterogeneity: An Application to Summer Jobs." American Economic Review, 107 (5): 546-50.

Fratzscher, M.,2012. "Capital flows, Push versus Pull Factors and the Global Financial Crisis". Journal of International Economics, 341-356.

Gelos, R., Sahay, R., and Sandleris, G., 2011. Sovereign Borrowing by Developing Countries: What Determines Market Access? Journal of International Economics, 243-254.

Guscina, A., Malik, S., and Papaioannou, M., 2017. “Assessing Loss of Market Access: Conceptual and Operational Issues". IMF Working Paper No 246.

Haque, T., Bogoev, J., and Smith, G., 2017. "Push and Pull: Emerging Risks in Frontier Economy Access to International Capital Markets". World Bank Group Discussion Paper No 17.

Hartelius, K., Kashiwase, K., and Kodres, L., 2008. "Emerging Market Spread Compression: Is it Real or is it Liquidity?" IMF Working Paper.

IMF, 2014. "Macroeconomic Developments in Low-Income Developing Countries: 2014 Report".

IMF, 2015. “The Fund's Lending Framework And Sovereign Debt - Further Considerations”.

IMF, 2019. "Macroeconomic Developments and Prospects in Low-Income Developing Countries”. IMF Policy Paper. 
IMF, 2020. "Eligibility to Use the Fund's Facilities for Concessional Financing, 2019". $\mathrm{SM} / 19 / 27$

Min, H.-C., Lee, D.-H., Nam, C., Park, M.-C., and Nam, S.-H., 2003. "Determinants of Emerging-Market Bond Spreads: Cross-Country Evidence”. Global Finance Journal, 271-286.

Mecagni, M., Kriljenko, J., Gueye, C., Mu, Y., Yabara, M., and Weber, S., 2014. “Issuing International Sovereign Bonds: Opportunities and Challenges for Sub-Saharan Africa". IMF Working Paper.

Presbitero, A., Ghura, D., Adedeji, O., and Njie, L., 2015. "International Sovereign Bonds by Emerging Markets and Developing Economies: Drivers of Issuance and Spreads". IMF Working Paper No 275.

Samarakoon, L., 2011. "Stock Market Interdependence, Contagion, and the U.S. Financial Crisis: The Case of Emerging and Frontier markets". Journal of International Financial Markets, Institutions \& Money, 724-742. 


\section{Appendix 1. Summary Statistics}

Table 9 - Summary Statistics

\begin{tabular}{|c|c|c|c|c|c|c|c|}
\hline Statistic & $\mathrm{N}$ & Mean & St. Dev. & Min & $\operatorname{Pctl}(25)$ & $\operatorname{Pctl}(75)$ & Max \\
\hline PPG Bond Disbursements (USD Billions) & 198 & 0.3 & 0.7 & 0 & 0 & 0 & 5 \\
\hline PPG Bond Stock (USD Billions) & 198 & 1.0 & 1.7 & 0 & 0 & 1.4 & 11 \\
\hline GDP Growth & 198 & 5.6 & 3.2 & -6.0 & 3.8 & 7.4 & 17.3 \\
\hline GDP per capita (USD Thousands) & 198 & 4.2 & 2.4 & 0.9 & 2.5 & 5.3 & 14.2 \\
\hline Government Debt to GDP & 187 & 41.4 & 18.7 & 8.6 & 28.4 & 52.4 & 119.9 \\
\hline Current Account to GDP & 198 & -7.2 & 10.4 & -41.8 & -10.1 & -2.7 & 27.2 \\
\hline Reserve in Months of Imports ( $\%$ GDP) & 198 & 12.2 & 6.7 & 3.6 & 7.9 & 14.8 & 34.4 \\
\hline Rule of Law percentile rank & 198 & 28.9 & 15.6 & 2.8 & 15.4 & 42.2 & 60.6 \\
\hline Private Credit to GDP & 169 & 23.5 & 13.1 & 2.7 & 15.1 & 27.5 & 63.9 \\
\hline EMBIG Index & 105 & 558.3 & 276.4 & 0.0 & 418.1 & 613.2 & $1,702.7$ \\
\hline Inflation rate & 198 & 6.8 & 5.1 & -2.2 & 3.2 & 9.3 & 33.2 \\
\hline US Growth & 198 & 1.9 & 1.5 & -2.5 & 1.6 & 2.6 & 2.9 \\
\hline VIX Index & 198 & 18.2 & 5.5 & 11.1 & 14.2 & 22.5 & 31.6 \\
\hline US 10 Years Bond Yield & 198 & 2.5 & 0.6 & 1.8 & 2.1 & 2.9 & 3.9 \\
\hline US policy interest rate & 198 & 0.6 & 0.8 & 0.1 & 0.1 & 1.4 & 2.4 \\
\hline
\end{tabular}




\section{Appendix 2: US Bond 10 Years Yields regressions}

Table 8A: PPG bonds to GDP regressions - 2009 to 2018

Dependent variable:

PPG Bond Stock

(1)

(2)

(3)

(4)

(5)

(6)

(7)

(8)

\begin{tabular}{|c|c|c|c|c|c|c|c|c|}
\hline \multirow[t]{2}{*}{ Log(GDPpc) (t-1) } & $1.096^{* *}$ & 0.613 & $1.096^{* *}$ & 0.295 & 0.380 & 1.260 & 0.318 & \begin{tabular}{|l|}
-0.373 \\
\end{tabular} \\
\hline & $(0.533)$ & (1.637) & $(0.503)$ & $(1.981)$ & $(0.363)$ & (1.015) & $(0.364)$ & (1.817) \\
\hline \multirow[t]{2}{*}{ GDP growth $(\mathrm{t}-1)$} & 0.016 & 0.002 & 0.009 & -0.004 & 0.050 & 0.056 & 0.047 & $0.057^{*}$ \\
\hline & $(0.043)$ & $(0.032)$ & $(0.042)$ & $(0.036)$ & $(0.052)$ & $(0.035)$ & $(0.052)$ & $(0.032)$ \\
\hline \multirow[t]{2}{*}{ Current Account to GDP (t-1) } & -0.004 & -0.028 & -0.015 & -0.026 & 0.015 & -0.003 & 0.011 & -0.003 \\
\hline & $(0.019)$ & $(0.019)$ & $(0.020)$ & $(0.022)$ & $(0.014)$ & $(0.007)$ & $(0.014)$ & $(0.007)$ \\
\hline \multirow[t]{2}{*}{ Reserves Assets/Months of Imports (t-1) } & -0.016 & -0.083 & -0.032 & -0.060 & -0.113 & -0.003 & -0.126 & -0.027 \\
\hline & $(0.136)$ & $(0.062)$ & $(0.110)$ & $(0.097)$ & $(0.090)$ & $(0.048)$ & $(0.080)$ & $(0.054)$ \\
\hline \multirow[t]{2}{*}{ Government Debt to GDP (t-1) } & $0.028^{*}$ & $0.054^{* * *}$ & 0.013 & $0.051^{* * *}$ & $0.034^{* * *}$ & $0.041^{* * *}$ & $0.028^{* *}$ & $0.039^{* *}$ \\
\hline & $(0.017)$ & $(0.017)$ & $(0.016)$ & $(0.015)$ & $(0.012)$ & $(0.015)$ & $(0.012)$ & $(0.017)$ \\
\hline \multirow[t]{2}{*}{ Inflation (t-1) } & $-0.099^{* * *}$ & -0.008 & $-0.101^{* *}$ & -0.021 & $-0.050^{*}$ & -0.010 & $-0.047^{*}$ & -0.018 \\
\hline & $(0.036)$ & $(0.035)$ & $(0.041)$ & $(0.038)$ & $(0.025)$ & $(0.019)$ & $(0.028)$ & $(0.023)$ \\
\hline \multirow[t]{2}{*}{ Private Credit to GDP (t-1) } & $0.050^{* *}$ & 0.029 & $0.051^{* * *}$ & 0.030 & $0.043^{* * *}$ & $0.067^{* * *}$ & $0.044^{* * *}$ & $0.071^{* * *}$ \\
\hline & $(0.020)$ & $(0.034)$ & $(0.019)$ & $(0.041)$ & $(0.013)$ & $(0.017)$ & $(0.013)$ & $(0.017)$ \\
\hline \multirow[t]{2}{*}{ IMF Support } & -0.428 & -0.114 & -0.394 & -0.053 & -0.282 & -0.149 & -0.330 & -0.208 \\
\hline & $(0.360)$ & $(0.290)$ & $(0.388)$ & $(0.260)$ & $(0.327)$ & $(0.168)$ & $(0.336)$ & $(0.159)$ \\
\hline \multirow[t]{2}{*}{ Rule of Law (t-1) } & $0.033^{* *}$ & $0.120^{* * *}$ & $0.036^{* *}$ & $0.136^{* * *}$ & $0.027^{* * *}$ & $0.046^{* * *}$ & $0.027^{* * *}$ & $0.050^{* *}$ \\
\hline & $(0.015)$ & $(0.033)$ & $(0.015)$ & $(0.031)$ & $(0.009)$ & $(0.018)$ & $(0.008)$ & $(0.020)$ \\
\hline \multirow[t]{2}{*}{ VIX Index } & -0.027 & 0.030 & & & -0.017 & 0.001 & & \\
\hline & $(0.026)$ & $(0.018)$ & & & $(0.017)$ & $(0.017)$ & & \\
\hline \multirow[t]{2}{*}{ US Bond 10yr yield (t-1) } & -0.267 & -0.233 & & & $-0.316^{* *}$ & $-0.240^{*}$ & & \\
\hline & $(0.246)$ & $(0.197)$ & & & $(0.138)$ & $(0.140)$ & & \\
\hline \multirow[t]{2}{*}{ EMBI } & -0.0003 & $-0.001^{* * *}$ & 0.0003 & $-0.001^{*}$ & & & & \\
\hline & $(0.001)$ & $(0.0004)$ & $(0.001)$ & $(0.001)$ & & & & \\
\hline \multirow[t]{2}{*}{ Constant } & -0.815 & & & & -0.368 & & & \\
\hline & $(1.314)$ & & & & (1.018) & & & \\
\hline
\end{tabular}


Pooling

Country FE

Time FE

Observations

$\mathrm{R}^{2}$

Adjusted R ${ }^{2}$

$\begin{array}{cccccccc}\text { Yes } & \text { No } & \text { No } & \text { No } & \text { Yes } & \text { No } & \text { No } & \text { No } \\ \text { No } & \text { Yes } & \text { No } & \text { Yes } & \text { No } & \text { Yes } & \text { No } & \text { Yes } \\ \text { No } & \text { No } & \text { Yes } & \text { Yes } & \text { No } & \text { No } & \text { Yes } & \text { Yes } \\ 103 & 103 & 103 & 103 & 183 & 183 & 183 & 183 \\ 0.620 & 0.571 & 0.589 & 0.282 & 0.539 & 0.561 & 0.433 & 0.256 \\ 0.569 & 0.432 & 0.488 & -0.061 & 0.509 & 0.482 & 0.367 & 0.072\end{array}$

*Robust and clustered standard errors by country. 
Table 8B: Probability of Issuance regressions - Non-Linear Marginal Effects

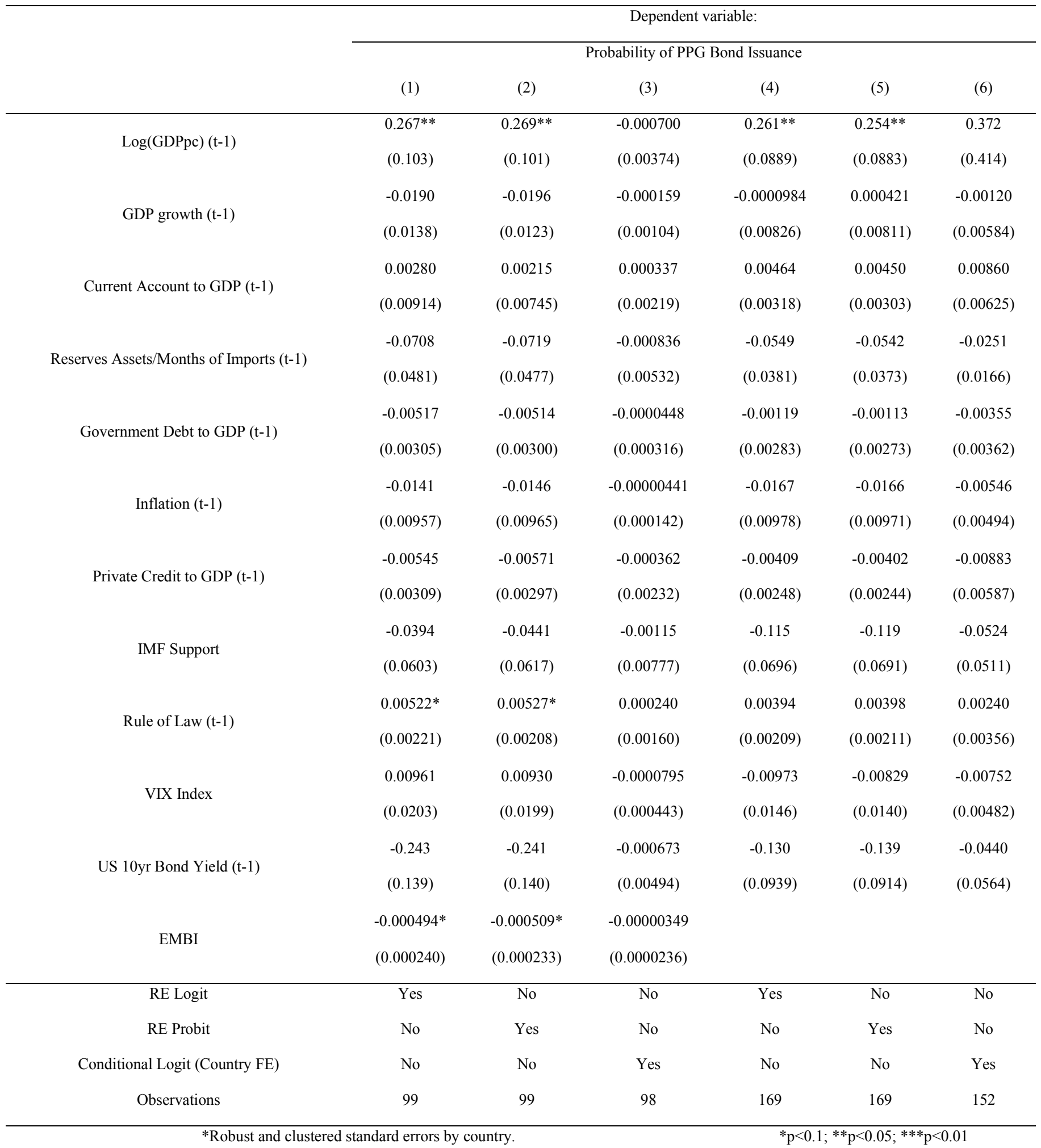

\section{CInternational Monetary Fund. Not for Redistribution}


Table 8C: Probability of Issuance regressions - LPM

Dependent variable:

Probability of PPG Bond Issuance

(1)

0.202

$\log (\mathrm{GDPpc})(\mathrm{t}-1)$

GDP growth (t-1)

Reserves Assets/Months of Imports (t-1)

Government Debt to GDP (t-1)

Inflation (t-1)

Private Credit to GDP (t-1)

IMF Support

Rule of Law (t-1)

VIX Index

US 10yr Bond Yield (t-1)

EMBI

Pooling
Country FE
Time FE
Observations

$(0.104)$

$-0.0139$

$(0.0134)$

0.000749

$(0.00619)$

$-0.0460$

$(0.0516)$

$-0.00286$

$(0.00286)$

$-0.0103$

(0.0103)

$-0.0304$

$(0.0711)$

(0.138)

$(0.297)$

Yes

No

No

99
(2)

(3)
(5)

(6)

(7)

(8)

(4)

$-0.180$

(0.732)

(0.0976)

$-0.00951$

$-0.0114$

(0.0124)

$(0.0151)$

$0.0402 * *$

(0.00965)

$-0.106$

(0.0703)

$-0.00581$

$(0.00619)$

$-0.000165$

(0.0130)

$-0.00504$

$-0.0388$

(0.00336)

(0.0149)

$-0.0598$

$-0.0178$

$(0.0745)$

$0.00364 *$

(0.125)

(0.00184)

0.0335 *

$0.00407^{*}$

(0.00183)

$0.00365 \quad-0.0270$

$(0.0211) \quad(0.0255)$

$-0.233 \quad-0.0552$

(0.143)

$-0.000213$

$-0.000129$

$(0.000205)$

$(0.000315)$

$-0.0000705$

0.00020

$1.245^{* * *}$

Yes
No
99
No

No

No
No
Yes
99

Yes

No
No
Yes
99

No

99

Yes

99

No
Yes
Yes

99

(1.070)

(0.0895)

0.293

$0.216^{*}$

(0.393)

$(0.0864)$

0.00521

0.000202

$-0.00602$

$-0.000286$

$(0.0127)$

(0.00881)

(0.0102)

(0.00876)

$.0429 * *$

$0.00484 \quad 0.00763$

0.00474

$(0.00259) \quad(0.00397)$

$(0.00280) \quad(0.00384)$

$-0.0564$

$-0.0599$

$-0.0730$

$-0.0600$

(0.0765)

(0.0345)

(0.0380)

(0.0346) (0.0386)

$-0.0063$

$-0.00056$

$-0.00370$

$-0.000388 \quad-0.00273$

$(0.00234)$

(0.00472)

$(0.00258) \quad(0.00461)$

$-0.00753$

$-0.0117$

$-0.00921$

$-0.011$

(0.0161)

$(0.00712) \quad(0.00825)$

$(0.00922) \quad(0.0109)$

$-0.0529 *$

$-0.00352$

$-0.0104$

$-0.00396 \quad-0.0116$

(0.0214)

$(0.00275)$

(0.00765)

(0.00284)

$-0.000422$

$-0.122$

$-0.131$

$-0.105$

$(0.127)$

(0.0659)

(0.0752)

$(0.0665)$

$0.0442 *$

0.00369

0.00864

0.00421

$0.0152)$

(0.00248)

(0.00753)

$(0.00233)$

$-0.0123 \quad-0.0195$

$(0.0127) \quad(0.0161)$

$\begin{array}{ll}-0.0784 & -0.0598\end{array}$

$(0.0890) \quad(0.0940)$

$0.832 * * *$

(0.196)

(0.735)

$-0.00584$

(0.0102)

0.00731

$-0.0703$

$-0.00753$

(0.00935)

$-0.0996$

(0.0744)

0.0114

(0.00825)

*Robust and clustered standard errors by country.

\begin{tabular}{cccc} 
Yes & No & No & No \\
No & Yes & No & Yes \\
No & No & Yes & Yes \\
169 & 169 & 169 & 169 \\
\hline & ${ }^{*} \mathrm{p}<0.1 ; * * \mathrm{p}<0.05 ; * * * \mathrm{p}<0.01$ &
\end{tabular}

\section{CInternational Monetary Fund. Not for Redistribution}




\section{Appendix 3: IMF ECF/SCF Support Arrangement}

Table 9A: PPG bonds to GDP regressions - 2009 to 2018

\begin{tabular}{|c|c|c|c|c|c|c|c|c|}
\hline & \multicolumn{8}{|c|}{ Dependent variable: } \\
\hline & \multicolumn{8}{|c|}{ PPG Bond Stock } \\
\hline & (1) & (2) & (3) & (4) & (5) & (6) & (7) & (8) \\
\hline \multirow[t]{2}{*}{$\log (\mathrm{GDPpc})(\mathrm{t}-1)$} & 0.662 & 0.157 & 0.698 & 0.328 & 0.244 & 1.460 & 0.178 & -0.274 \\
\hline & $(0.579)$ & $(1.550)$ & $(0.575)$ & $(1.881)$ & $(0.370)$ & $(1.130)$ & $(0.368)$ & $(1.823)$ \\
\hline \multirow[t]{2}{*}{ GDP growth $(\mathrm{t}-1)$} & 0.025 & 0.007 & 0.018 & -0.001 & 0.050 & $0.064^{*}$ & 0.050 & $0.060^{*}$ \\
\hline & $(0.039)$ & $(0.028)$ & $(0.037)$ & $(0.035)$ & $(0.051)$ & $(0.034)$ & $(0.051)$ & $(0.031)$ \\
\hline \multirow[t]{2}{*}{ Current Account to GDP (t-1) } & 0.0001 & $-0.035^{*}$ & -0.011 & $-0.039^{*}$ & 0.016 & -0.007 & 0.012 & -0.006 \\
\hline & $(0.020)$ & $(0.019)$ & $(0.021)$ & $(0.022)$ & $(0.014)$ & $(0.007)$ & $(0.015)$ & $(0.008)$ \\
\hline \multirow[t]{2}{*}{ Reserves Assets/Months of Imports (t-1) } & 0.028 & $-0.096^{* *}$ & 0.035 & -0.039 & -0.103 & -0.031 & -0.087 & -0.017 \\
\hline & $(0.156)$ & $(0.047)$ & $(0.108)$ & $(0.090)$ & $(0.094)$ & $(0.052)$ & $(0.087)$ & $(0.050)$ \\
\hline \multirow[t]{2}{*}{ Government Debt to GDP (t-1) } & 0.024 & $0.056^{* * *}$ & 0.010 & $0.055^{* * *}$ & $0.032^{* * *}$ & $0.044^{* * *}$ & $0.027^{* *}$ & $0.041^{* *}$ \\
\hline & $(0.015)$ & $(0.016)$ & $(0.015)$ & $(0.013)$ & $(0.011)$ & $(0.015)$ & $(0.012)$ & $(0.016)$ \\
\hline \multirow[t]{2}{*}{ Inflation (t-1) } & $-0.075^{* *}$ & -0.005 & $-0.083^{* *}$ & -0.021 & $-0.044^{* *}$ & -0.001 & $-0.047^{*}$ & -0.017 \\
\hline & $(0.031)$ & $(0.040)$ & $(0.038)$ & $(0.038)$ & $(0.022)$ & $(0.016)$ & $(0.025)$ & $(0.022)$ \\
\hline \multirow[t]{2}{*}{ Private Credit to GDP (t-1) } & $0.066^{* * *}$ & 0.045 & $0.066^{* * *}$ & 0.045 & $0.051^{* * *}$ & $0.069^{* * *}$ & $0.051^{* * *}$ & $0.072^{* * *}$ \\
\hline & $(0.023)$ & $(0.042)$ & $(0.022)$ & $(0.040)$ & $(0.016)$ & $(0.016)$ & $(0.016)$ & $(0.016)$ \\
\hline \multirow[t]{2}{*}{ IMF PRGT-ECF Support } & 0.225 & 0.035 & 0.159 & 0.033 & 0.083 & -0.189 & 0.050 & -0.227 \\
\hline & $(0.595)$ & $(0.277)$ & $(0.638)$ & $(0.353)$ & $(0.459)$ & $(0.186)$ & $(0.465)$ & $(0.219)$ \\
\hline \multirow[t]{2}{*}{ IMF PRGT-SCF Support } & $-0.963^{* * *}$ & $-0.928^{* * *}$ & $-1.023^{* * *}$ & $-0.850^{* * *}$ & $-0.625^{*}$ & $-0.793^{* * *}$ & $-0.607^{*}$ & $-0.642^{* * *}$ \\
\hline & $(0.274)$ & $(0.288)$ & $(0.378)$ & $(0.290)$ & $(0.341)$ & $(0.184)$ & $(0.314)$ & $(0.152)$ \\
\hline \multirow[t]{2}{*}{ Rule of Law (t-1) } & $0.032^{* *}$ & $0.128^{* * *}$ & $0.036^{* *}$ & $0.137^{* * *}$ & $0.027^{* * *}$ & $0.052^{* * *}$ & $0.027^{* * *}$ & $0.051^{* * *}$ \\
\hline & $(0.016)$ & $(0.033)$ & $(0.016)$ & $(0.031)$ & $(0.009)$ & $(0.017)$ & $(0.009)$ & $(0.020)$ \\
\hline \multirow[t]{2}{*}{ VIX Index } & $-0.055^{* *}$ & 0.012 & & & $-0.038^{* *}$ & -0.014 & & \\
\hline & $(0.027)$ & $(0.022)$ & & & $(0.017)$ & $(0.018)$ & & \\
\hline US Bond 10yr yield (t-1) & 0.101 & -0.001 & & & $0.049^{*}$ & -0.034 & & \\
\hline
\end{tabular}




\begin{tabular}{|c|c|c|c|c|c|c|c|c|}
\hline & $(0.073)$ & $(0.125)$ & & & $(0.027)$ & $(0.028)$ & & \\
\hline \multirow[t]{2}{*}{ EMBI } & -0.0002 & $-0.001^{* *}$ & 0.0004 & $-0.001^{* *}$ & & & & \\
\hline & $(0.001)$ & $(0.001)$ & $(0.001)$ & $(0.0005)$ & & & & \\
\hline \multirow[t]{2}{*}{ Constant } & -1.361 & & & & -1.017 & & & \\
\hline & (1.068) & & & & $(0.886)$ & & & \\
\hline Pooling & Yes & No & No & No & Yes & No & No & No \\
\hline Country FE & No & Yes & No & Yes & No & Yes & No & Yes \\
\hline Time FE & No & No & Yes & Yes & No & No & Yes & Yes \\
\hline Observations & 103 & 103 & 103 & 103 & 183 & 183 & 183 & 183 \\
\hline $\mathrm{R}^{2}$ & 0.622 & 0.591 & 0.597 & 0.321 & 0.533 & 0.571 & 0.432 & 0.272 \\
\hline Adjusted $\mathrm{R}^{2}$ & 0.567 & 0.452 & 0.493 & -0.019 & 0.500 & 0.489 & 0.362 & 0.086 \\
\hline
\end{tabular}


Table 9B: Probability of Issuance regressions - Non-Linear Marginal Effects

Dependent variable:

Probability of PPG Bond Issuance

(1)

(2)

0.165

$\log (\mathrm{GDPpc})(\mathrm{t}-1)$

GDP growth (t-1)

Reserves Assets/Months of Imports (t-1)

Government Debt to GDP (t-1)

Inflation (t-1)

Private Credit to GDP (t-1)

IMF PRGT-ECF Support

IMF PRGT-SCF Support

Rule of Law (t-1)

VIX Index

US growth (t-1)

EMBI

(0.132)

$\begin{array}{ll}-0.0165 & -0.0178\end{array}$

(0.0144)

$(0.0130)$

0.00450

0.00360

(0.00869)

(0.00712)

$$
-0.0515
$$

$-0.0533$

(0.0471)

$(0.0453)$

-0.00640 *

-0.00649 *

(0.00298)

(0.00278)

$-0.00986$

$-0.0104$

(0.0112)

(0.0114)

$-0.00163$

$-0.00215$

(0.00375)

(0.00369)

$-0.0528$

$(0.100)$

$-0.0569$

$-0.315$

(0.193)

$(0.102)$

$-0.284$

(0.163)

0.00573*

$0.00590^{*}$

(0.00268)

(0.00245)

$-0.0264 * *$

$-0.0264 * *$

(0.00996)

(0.00930)

0.0515

0.0522

(0.0468)

(0.0464)

$-0.000400$

$-0.000423 *$

(0.000212)
(3)

$-0.00445$

(0.0209)

$-0.000233$

$(0.00134)$

0.000495

(0.00283)

$-0.00107$

(0.00604)

$-0.0000531$

(0.000334)

0.0000543

(0.000416)

$-0.000529$

(0.00303)

$-0.0274$

(0.158)

$-0.0552$

(0.319)

0.000427

(0.00247)

$-0.000258$

(0.00138)

0.000410

(0.00240)

$-0.00000594$

(0.0000334)
(4)

(5)

(6)

0.214

$0.209^{*}$

(0.0845)

$(0.0811)$

$-0.00365 \quad-0.00363$

$(0.00816) \quad(0.00776)$

$0.00424 \quad 0.00404$

(0.00284)

(0.00272)

$-0.0626$

$-0.0638$

(0.0361)

(0.0334)

(0.0204)

$-0.00353$

$-0.00351$

$-0.00625$

(0.00259)

(0.00248)

(0.00430)

$-0.0131$

$-0.0129$

$-0.00496$

$(0.00969) \quad(0.00950)$

(0.00657)

$-0.00277$

$-0.00282$

(0.00283)

(0.00264)

$-0.0123 *$

$-0.152 *$

$-0.158^{*}$

(0.00535)

(0.0681)

(0.0667)

$-0.186^{*}$

-0.300 *

$-0.282 *$

(0.0857)

(0.149)

(0.127)

$-0.278^{*}$

$0.00465^{*}$

$0.00477 *$

(0.142)

(0.00210)

(0.00205)

0.00510

$-0.0195$

$-0.0187^{*}$

(0.00553)

$\begin{array}{lll}(0.00998) & (0.00837) \quad(0.00559)\end{array}$

$\begin{array}{lll}0.0216 & 0.0214 & 0.0143\end{array}$

$(0.0171)$

(0.0158)

(0.0112)

\begin{tabular}{ccccccc}
\hline RE Logit & Yes & No & No & Nes \\
RE Probit & No & Yes & No & No & Yes & No \\
Conditional Logit (Country FE) & No & No & No & 102 & 183 \\
Observations & 103 & 103 & 183 \\
\hline
\end{tabular}

*Robust and clustered standard errors by country.

${ }^{*} \mathrm{p}<0.1 ; * * \mathrm{p}<0.05 ; * * * \mathrm{p}<0.01$

\section{CInternational Monetary Fund. Not for Redistribution}


Table 9C: Probability of Issuance regressions - LPM

Dependent variable:

Probability of PPG Bond Issuance

(1)

0.134

$\log (\mathrm{GDPpc})(\mathrm{t}-1)$

Government Debt to GDP (t-1)

Inflation (t-1)

Private Credit to GDP (t-1)

IMF PRGT-ECF Support

IMF PRGT-SCF Support

Rule of Law (t-1)

VIX Index

EMBI

Constant

$(0.128)$

$-0.0119$

$(0.0134)$

0.00180

$(0.00631)$

$-0.0377$

(0.0424)

$-0.00430$

(0.00231)

$-0.00847$

$(0.0126)$

$-0.00182$

$(0.00397)$

$-0.0501$

(0.113)

$-0.220$

(0.154)

(2)

(0.730)

$-0.0102$

(0.0129)

$0.0331 * *$

(0.00804)

-0.117 *

(0.0530)

$-0.00601$

(0.00599)

0.000606

(0.0170)

$-0.0272$

(0.0151)

$-0.220$

(0.185)

$-0.367$

0.00401

(0.264)

0.0297 **

(0.00224)

(0.00968)

$-0.0267 * * *$

$-0.0265^{*}$

(0.00780)

(0.0116)

0.0171

$-0.00512$

(0.0413)

$-0.0000970$

(0.0447)

(0.000218)

(0.000176)

$1.105^{* * *}$

(0.284)
(3)

(4)

(5)

0.204

(0.116)

$-0.0115$

(0.0119)

0.000593

(0.00619)

$-0.0239$

(0.0458)

$-0.00352$

$(0.00260)$

$-0.0128$

(0.0116)

$-0.00369$

(0.00403)

$-0.0682$

(0.0985)

$-0.202$

(0.155)

1.004

(1.135)

$-0.00938$

(0.00991)

$0.0328 * *$

(0.0104)

$-0.0678$

(0.0604)

$-0.00552$

(0.00703)

$-0.00623$

(0.0179)

-0.0431 *

(0.0184)

$-0.209$

(0.153)

$-0.315$

(0.285)

0.00392

0.0364*

(0.0152)

(0.00241)

$-0.0152 * *$

(0.00533)

$0.00929 \quad 0.00473$

(0.0104)

(0.0122)

$(0.0790)$

(0.418)

$-0.000827$

$-0.00583$

0.00390

(0.00893)

(0.00280)

$(0.00334)$

0.0692

$-0.0874 *$

$-0.00143$

$-0.00427$

(0.00211)

$(0.00484)$

$-0.00693$

0.000922

$-0.00179$

$-0.00675$

$-0.135 *$

$-0.159$

(0.0847)

-0.247 *

$-0.341^{* *}$

(0.114)

0.00378

0.00867
(6)

(7)

(8)

458

(0.746)

(0.0822)

$-0.00384$

$-0.00633$

(0.00799)

(0.00913)

(0.00273)

(0.00336)

$-0.0707 *$

$-0.0785^{*}$

(0.0323) (0.0292)

(0.0345)

$-0.00282$

$-0.00376$

(0.00273)

(0.00476)

$-0.00497$

0.000704

$\begin{array}{lll}(0.00646) & (0.00648) & (0.00752)\end{array}$

$(0.00885)$

$-0.00288$

$-0.00809$

$\begin{array}{lll}(0.00301) & (0.00619) \quad(0.00368)\end{array}$

$(0.00697)$

$-0.157^{*}$

$-0.146$

$(0.0644)$

$(0.0801)$

$-0.283 * *$

$-0.334 *$

(0.0882)

$(0.117)$

0.00482

0.0102

$(0.00889) \quad(0.00273) \quad(0.00943)$

$-0.0000319$

0.000152

$(0.000192)$

$(0.000162)$
$-0.0185^{*}$

$0.00658)$ 
Table 9D: EMBIG regressions - 2009 to 2018

Dependent variable:

EMBIG Index

(1) (2) (3)

\begin{tabular}{|c|c|c|c|c|}
\hline \multirow[t]{2}{*}{$\log (\mathrm{GDPpc})(\mathrm{t}-1)$} & -55.843 & $-1,052.293^{* * *}$ & -53.175 & $-1,083.911^{* * *}$ \\
\hline & $(74.493)$ & $(166.963)$ & $(71.648)$ & $(346.990)$ \\
\hline \multirow{2}{*}{ GDP growth (t-1) } & $-24.123^{* * *}$ & -9.856 & $-21.683^{* *}$ & -8.186 \\
\hline & $(8.780)$ & $(6.732)$ & $(8.713)$ & $(6.907)$ \\
\hline \multirow[t]{2}{*}{ Current Account to GDP (t-1) } & $-8.496^{* *}$ & -4.563 & $-7.448^{* *}$ & -6.101 \\
\hline & $(3.897)$ & $(4.882)$ & $(3.431)$ & $(4.412)$ \\
\hline \multirow[t]{2}{*}{ Reserves Assets/Months of Imports (t-1) } & $-39.997^{*}$ & $-61.748^{* * *}$ & $-39.491^{*}$ & $-83.339^{* * *}$ \\
\hline & $(22.425)$ & $(20.982)$ & $(21.313)$ & $(27.232)$ \\
\hline \multirow[t]{2}{*}{ Government Debt to GDP (t-1) } & $4.122^{* *}$ & $8.335^{* * *}$ & $5.542^{* * *}$ & $7.811^{* * *}$ \\
\hline & $(1.912)$ & $(2.882)$ & $(1.947)$ & $(2.510)$ \\
\hline \multirow[t]{2}{*}{ Inflation (t-1) } & $11.719^{*}$ & $19.039^{* * *}$ & $11.668^{* *}$ & $20.613^{* * *}$ \\
\hline & $(6.559)$ & $(7.325)$ & $(5.802)$ & $(5.767)$ \\
\hline \multirow[t]{2}{*}{ Private Credit to GDP (t-1) } & -2.880 & $12.976^{*}$ & -2.482 & $16.776^{*}$ \\
\hline & $(2.276)$ & $(7.511)$ & $(2.169)$ & $(8.907)$ \\
\hline \multirow[t]{2}{*}{ IMF PRGT-ECF Support } & 32.234 & -108.741 & 43.466 & $-122.070^{* * *}$ \\
\hline & $(43.416)$ & $(75.232)$ & $(39.636)$ & $(44.319)$ \\
\hline \multirow[t]{2}{*}{ IMF PRGT-SCF Support } & 54.126 & 27.344 & 31.853 & -27.784 \\
\hline & $(106.018)$ & $(104.262)$ & (85.619) & $(86.826)$ \\
\hline \multirow[t]{2}{*}{ Rule of Law (t-1) } & -1.314 & 0.352 & -1.893 & -2.627 \\
\hline & $(1.033)$ & $(4.749)$ & $(1.209)$ & $(3.640)$ \\
\hline \multirow[t]{2}{*}{ VIX Index } & $14.603^{* *}$ & 3.231 & & \\
\hline & $(6.961)$ & $(6.969)$ & & \\
\hline \multirow[t]{2}{*}{ US growth (t-1) } & $58.674^{* * *}$ & $96.088^{* * *}$ & & \\
\hline & (12.757) & $(13.274)$ & & \\
\hline
\end{tabular}


Constant

Time FE

Observations

$\mathrm{R}^{2}$

Adjusted R ${ }^{2}$
$324.448^{* *}$

$(163.742)$

\begin{tabular}{|c|c|c|c|c|}
\hline Pooling & Yes & No & No & No \\
\hline Country FE & No & Yes & No & Yes \\
\hline Time FE & No & No & Yes & Yes \\
\hline Observations & 99 & 99 & 99 & 99 \\
\hline $\mathrm{R}^{2}$ & 0.524 & 0.487 & 0.551 & 0.482 \\
\hline Adjusted $\mathrm{R}^{2}$ & 0.458 & 0.330 & 0.436 & 0.242 \\
\hline
\end{tabular}

*Robust and clustered standard errors by country. 


\section{Appendix 4: VIX x Rule of Law interactions}

Table 10A: PPG bonds to GDP regressions - 2009 to 2018

\begin{tabular}{|c|c|c|c|c|c|c|c|c|}
\hline & & & & Dependent & variable: & & & \\
\hline & & & & PPG Bor & Stock & & & \\
\hline $\log (\mathrm{GDPpc})(\mathrm{t}-1)$ & $1.041^{* *}$ & 0.530 & $1.046^{* *}$ & 0.418 & 0.360 & 1.669 & 0.283 & -0.645 \\
\hline GDP growth (t-1) & 0.022 & 0.003 & 0.014 & -0.004 & 0.050 & $0.061^{*}$ & 0.048 & $0.055^{*}$ \\
\hline & $(0.044)$ & $(0.029)$ & $(0.040)$ & $(0.035)$ & $(0.052)$ & $(0.035)$ & $(0.051)$ & $(0.031)$ \\
\hline Reserves Assets/Months of Imports (t-1) & -0.035 & $-0.111^{* *}$ & -0.050 & -0.057 & -0.123 & -0.031 & -0.115 & -0.024 \\
\hline & $(0.144)$ & $(0.052)$ & $(0.108)$ & $(0.094)$ & $(0.088)$ & $(0.045)$ & $(0.081)$ & $(0.054)$ \\
\hline Government Debt to GDP (t-1) & 0.023 & $0.055^{* * *}$ & 0.004 & $0.052^{* * *}$ & $0.031^{* * *}$ & $0.038^{* *}$ & $0.026^{* *}$ & $0.034^{* *}$ \\
\hline & $(0.017)$ & $(0.018)$ & $(0.015)$ & $(0.018)$ & $(0.011)$ & $(0.016)$ & $(0.012)$ & $(0.017)$ \\
\hline Inflation (t-1) & $-0.092^{* * *}$ & -0.005 & $-0.096^{* *}$ & -0.021 & $-0.043^{*}$ & -0.0003 & $-0.046^{*}$ & -0.018 \\
\hline & $(0.030)$ & $(0.042)$ & $(0.037)$ & $(0.038)$ & $(0.024)$ & $(0.016)$ & $(0.027)$ & $(0.022)$ \\
\hline & $(0.361)$ & $(0.313)$ & $(0.380)$ & $(0.283)$ & $(0.329)$ & $(0.176)$ & $(0.335)$ & $(0.157)$ \\
\hline Rule of Law (t-1) & $0.081^{*}$ & $0.116^{* *}$ & $0.102^{* * *}$ & $0.133^{* * *}$ & $0.070^{* * *}$ & $0.064^{* *}$ & $0.070^{* * *}$ & $0.069^{* *}$ \\
\hline & $(0.042)$ & $(0.053)$ & $(0.035)$ & $(0.044)$ & $(0.024)$ & $(0.028)$ & $(0.024)$ & $(0.028)$ \\
\hline VIX Index & 0.030 & 0.005 & & & 0.028 & 0.015 & & \\
\hline & $(0.026)$ & $(0.036)$ & & & $(0.027)$ & $(0.035)$ & & \\
\hline US growth $(\mathrm{t}-1)$ & 0.034 & -0.022 & & & 0.036 & -0.030 & & \\
\hline & $(0.061)$ & $(0.134)$ & & & $(0.025)$ & $(0.028)$ & & \\
\hline EMBI & -0.0001 & $-0.001^{*}$ & 0.001 & -0.001 & & & & \\
\hline
\end{tabular}




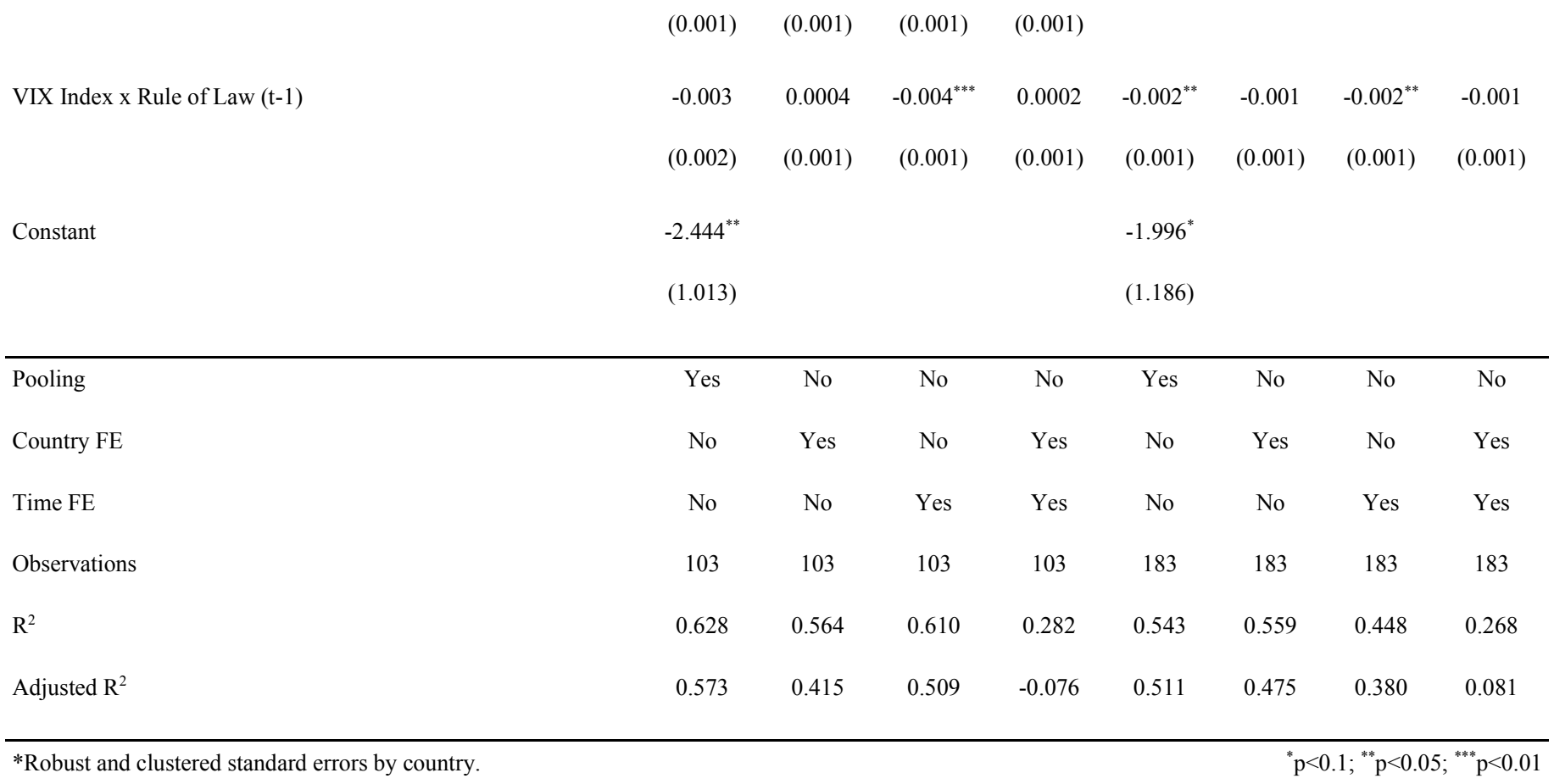


Table 10B: Probability of Issuance regressions - LPM

Dependent variable:

Probability of PPG Bond Issuance

(1)

0.195

$\log (\mathrm{GDPpc})(\mathrm{t}-1)$

GDP growth (t-1)

Reserves Assets/Months of Imports (t-1)

Government Debt to GDP (t-1)

Inflation (t-1)

Private Credit to GDP (t-1)

IMF Support

Rule of Law (t-1)

VIX Index

US growth (t-1)

EMBI

VIX Index x Rule of Law (t-1)

Constant

(0.411)

Pooling
Country FE

Time FE

Observations

$-0.0121$

$(0.0135)$

(0.00653)

$-0.0450$

$(0.00354)$
(2)

(3)

(4)

(5)

(6)

(7)

(8)

$0.200^{* *}$

0.432

(0.0758)

(0.388)

0.000490

$-0.00597$

$(0.0746)$

$(0.755)$

$-0.0100$

$-0.0115$

$-0.00919$

(0.0121)

(0.0122)

(0.00908)

(0.00935)

0.000173

$-0.00632$

(0.0129)

0.00114

$0.0374 * *$

0.00435

0.00646

(0.00883)

(0.00943)

(0.00759)

(0.00658)

(0.0106)

(0.00285)

(0.00359)

0.00436

0.00628

$-0.122$

$-0.0271$

$-0.0616$

$-0.0703 *$

$-0.0920^{*}$

(0.0643)

(0.0298)

(0.0331)

$-0.00494$

$-0.000586$

$-0.00488$

(0.00732)

(0.00205)

(0.00454)

$-0.00830$

$-0.00734$

0.000869

(0.0179)

(0.00670)

$-0.0498^{*}$

$-0.00284$

(0.00689)

$-0.00788$

(0.00212)

(0.00643)

(0.0154)

(0.00334)

(0.0200)
$(0.00292) \quad(0.00357)$

$-0.0605 * \quad-0.0800$ *

$(0.0307) \quad(0.0344)$

$\begin{array}{ll}-0.0000956 & -0.00347\end{array}$

$(0.00213) \quad(0.00429)$

$-0.00887 \quad-0.000158$

$(0.00789) \quad(0.00957)$

$\begin{array}{ll}-0.00326 & -0.00836\end{array}$

$(0.00220) \quad(0.00766)$

$\begin{array}{ll}-0.0852 & -0.0604\end{array}$

$(0.0674) \quad(0.0696)$

$0 \quad 0$

(.)

(.)
$-0.0284$

$-0.0181$

(0.0744)

(0.135)

0

(.)

(0.0177)

$-0.0267$

$-0.0317^{*}$

(0.0196)

$0.0105 \quad-0.0141$

(0.0437)

(0.0474)

$-0.000148$

(0.000204)

$-0.0000679$

$-0.0000875$

0.000158

0.000235

(0.000519)

$(0.000220)$

(0.000183)

$(0.000223)$

0.0000260

0.000312

0.000253

(0.000522)

(0.000439)

$-1.320$

1.867

(0.946)

(2.417)

(2.110)

$\begin{array}{ll}-0.0995 & -0.0834\end{array}$

(0.0698)

0

(.)

$-0.0227^{*}$

(0.00940)

(0.00949)

$0.00118 \quad 0.000207$

$(0.0125) \quad(0.0131)$

No

Yes

No

No

Yes

No

103

No

Yes

103

103

No

Yes

Yes

103 
Table 10C: EMBIG regressions - 2009 to 2018

Dependent variable: EMBIG Index
(1)
(2)
(3)
(4)

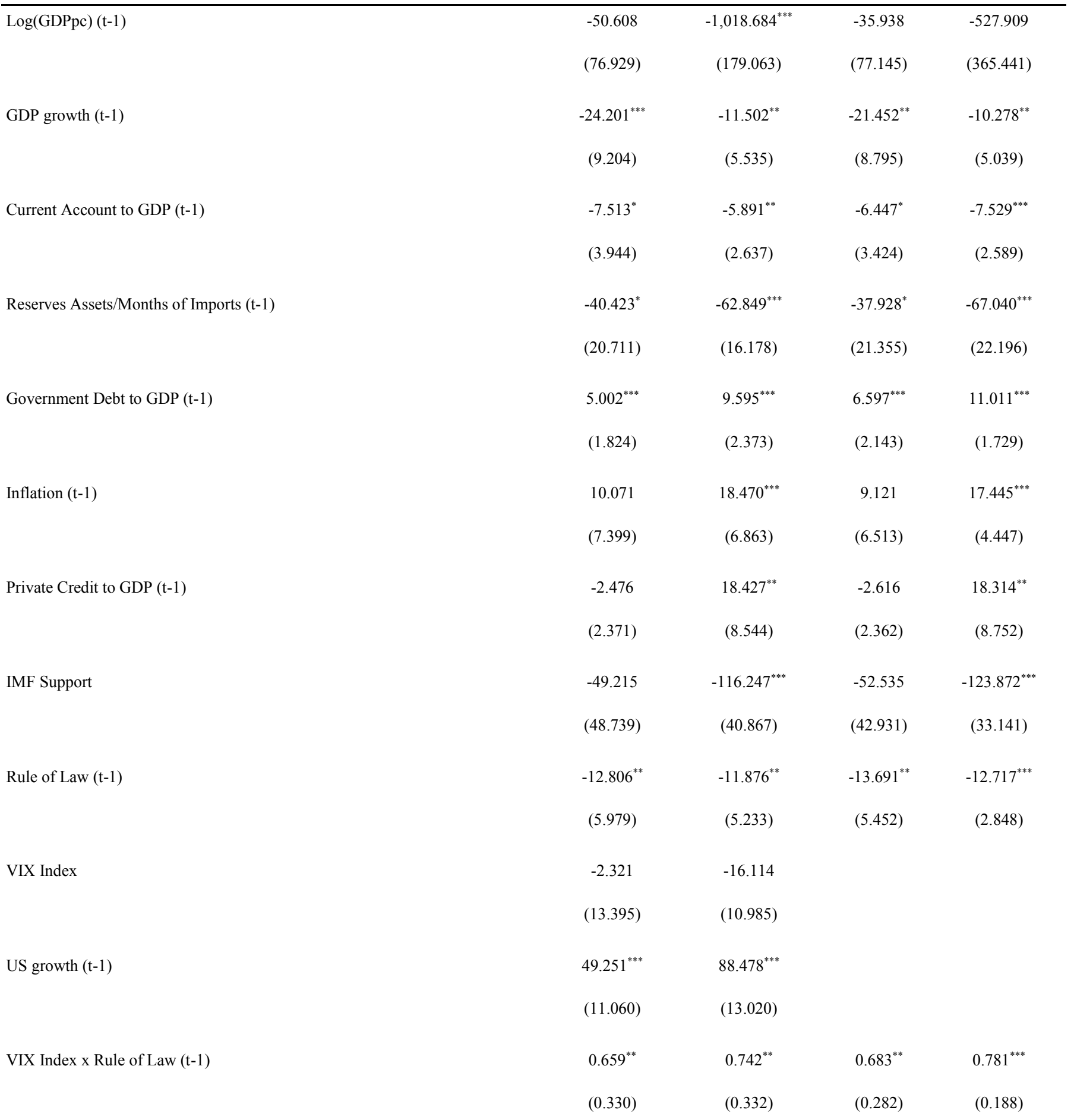


Constant

$643.880^{* * *}$

$(221.852)$

Pooling

Country FE

Time FE

Observations

$\mathrm{R}^{2}$

Adjusted $\mathrm{R}^{2}$

*Robust and clustered standard errors by country.
Yes

No

No

99

0.550

0.487

$\begin{array}{ccc}\text { No } & \text { No } & \text { No } \\ \text { Yes } & \text { No } & \text { Yes } \\ \text { No } & \text { Yes } & \text { Yes } \\ 99 & 99 & 99 \\ 0.546 & 0.580 & 0.551 \\ 0.407 & 0.472 & 0.343 \\ & & \\ & & \\ & & \end{array}$




\section{Appendix 5: Bloomberg Commodities Index (BCOM)}

Table 11A: PPG bonds to GDP regressions - 2009 to 2018

\begin{tabular}{|c|c|c|c|c|c|c|c|c|}
\hline & \multicolumn{8}{|c|}{ Dependent variable: } \\
\hline & \multicolumn{8}{|c|}{ PPG Bond Stock } \\
\hline & (1) & $(2)$ & (3) & (4) & $(5)$ & (6) & (7) & $(8)$ \\
\hline \multirow[t]{2}{*}{$\log (\mathrm{GDPpc})(\mathrm{t}-1)$} & $1.074^{* *}$ & 0.480 & $1.096^{* *}$ & 0.295 & 0.351 & 0.751 & 0.318 & -0.373 \\
\hline & $(0.517)$ & $(1.835)$ & $(0.503)$ & $(1.981)$ & $(0.368)$ & $(1.346)$ & $(0.364)$ & $(1.817)$ \\
\hline \multirow[t]{2}{*}{ GDP growth $(\mathrm{t}-1)$} & 0.012 & 0.004 & 0.009 & -0.004 & 0.049 & $0.063^{*}$ & 0.047 & $0.057^{*}$ \\
\hline & $(0.040)$ & $(0.030)$ & $(0.042)$ & $(0.036)$ & $(0.053)$ & $(0.035)$ & $(0.052)$ & $(0.032)$ \\
\hline \multirow[t]{2}{*}{ Current Account to GDP (t-1) } & -0.011 & -0.027 & -0.015 & -0.026 & 0.011 & -0.004 & 0.011 & -0.003 \\
\hline & $(0.019)$ & $(0.019)$ & $(0.020)$ & $(0.022)$ & $(0.015)$ & $(0.007)$ & $(0.014)$ & $(0.007)$ \\
\hline \multirow[t]{2}{*}{ Reserves Assets/Months of Imports (t-1) } & -0.057 & $-0.111^{* *}$ & -0.032 & -0.060 & -0.131 & -0.039 & -0.126 & -0.027 \\
\hline & $(0.135)$ & $(0.051)$ & $(0.110)$ & $(0.097)$ & $(0.086)$ & $(0.048)$ & $(0.080)$ & $(0.054)$ \\
\hline \multirow[t]{2}{*}{ Government Debt to GDP (t-1) } & 0.019 & $0.054^{* * *}$ & 0.013 & $0.051^{* * *}$ & $0.028^{* *}$ & $0.038^{* *}$ & $0.028^{* *}$ & $0.039^{* *}$ \\
\hline & $(0.016)$ & $(0.018)$ & $(0.016)$ & $(0.015)$ & $(0.011)$ & $(0.017)$ & $(0.012)$ & $(0.017)$ \\
\hline \multirow[t]{2}{*}{ Inflation (t-1) } & $-0.095^{* * *}$ & -0.006 & $-0.101^{* *}$ & -0.021 & $-0.042^{*}$ & -0.005 & $-0.047^{*}$ & -0.018 \\
\hline & $(0.035)$ & $(0.041)$ & $(0.041)$ & $(0.038)$ & $(0.024)$ & $(0.016)$ & $(0.028)$ & $(0.023)$ \\
\hline \multirow[t]{2}{*}{ Private Credit to GDP (t-1) } & $0.051^{* * *}$ & 0.028 & $0.051^{* * *}$ & 0.030 & $0.044^{* * *}$ & $0.065^{* * *}$ & $0.044^{* * *}$ & $0.071^{* * *}$ \\
\hline & $(0.019)$ & $(0.042)$ & $(0.019)$ & $(0.041)$ & $(0.013)$ & $(0.016)$ & $(0.013)$ & $(0.017)$ \\
\hline \multirow[t]{2}{*}{ IMF Support } & -0.464 & -0.131 & -0.394 & -0.053 & -0.339 & -0.221 & -0.330 & -0.208 \\
\hline & $(0.375)$ & $(0.282)$ & $(0.388)$ & $(0.260)$ & $(0.337)$ & $(0.161)$ & $(0.336)$ & $(0.159)$ \\
\hline \multirow[t]{2}{*}{ Rule of Law (t-1) } & $0.033^{* *}$ & $0.121^{* * *}$ & $0.036^{* *}$ & $0.136^{* * *}$ & $0.026^{* * *}$ & $0.043^{* *}$ & $0.027^{* * *}$ & $0.050^{* *}$ \\
\hline & $(0.015)$ & $(0.033)$ & $(0.015)$ & $(0.031)$ & $(0.008)$ & $(0.019)$ & $(0.008)$ & $(0.020)$ \\
\hline \multirow[t]{2}{*}{ VIX Index } & -0.027 & 0.014 & & & -0.019 & -0.015 & & \\
\hline & $(0.021)$ & $(0.026)$ & & & $(0.014)$ & $(0.019)$ & & \\
\hline \multirow[t]{2}{*}{ US growth (t-1) } & -0.080 & -0.022 & & & -0.008 & -0.028 & & \\
\hline & $(0.071)$ & $(0.135)$ & & & $(0.027)$ & $(0.033)$ & & \\
\hline \multirow[t]{2}{*}{ BCOM Index } & $-0.098^{* * *}$ & -0.004 & & & $-0.075^{* * *}$ & -0.046 & & \\
\hline & $(0.031)$ & $(0.035)$ & & & $(0.020)$ & $(0.034)$ & & \\
\hline
\end{tabular}




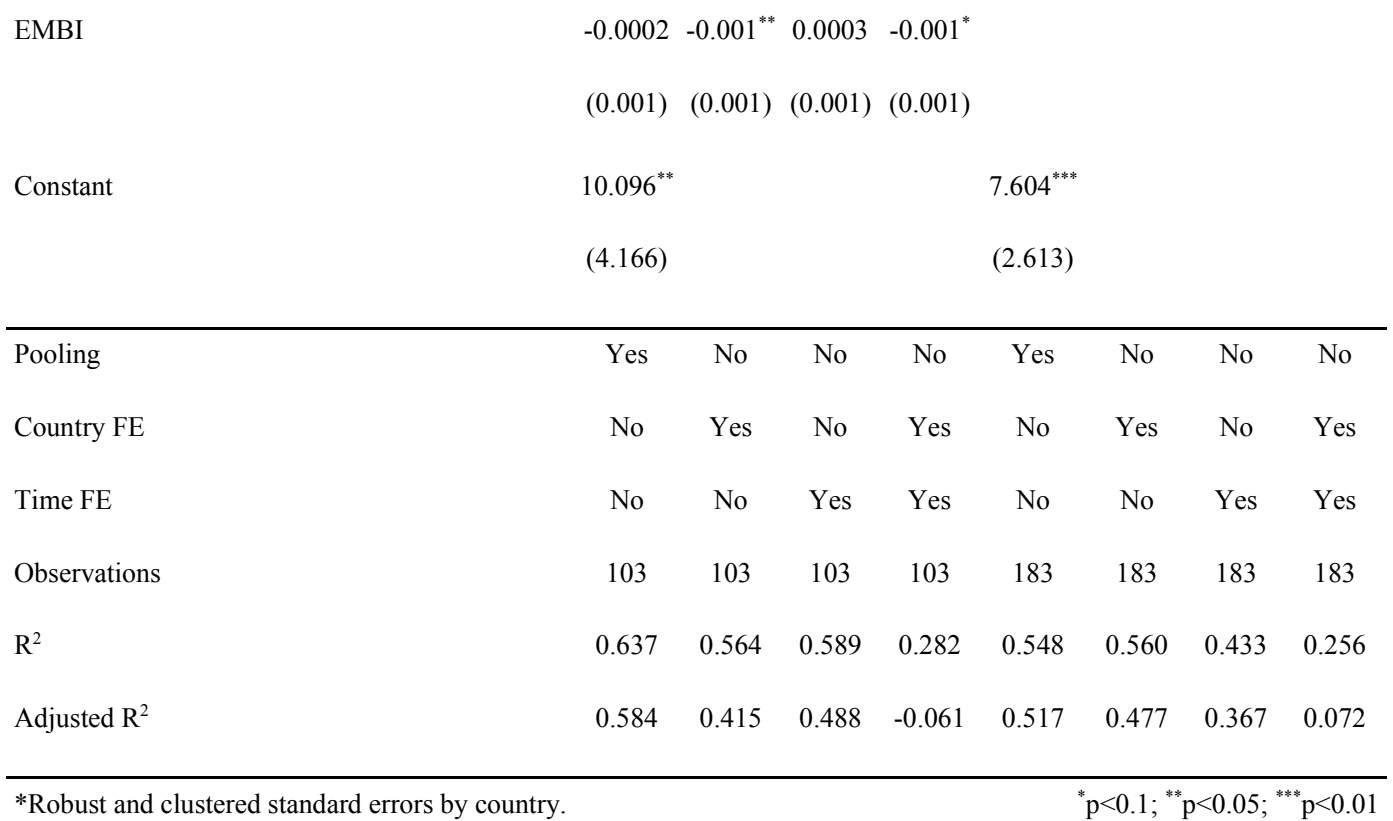


Table 11B: Probability of Issuance regressions - Non-Linear Marginal Effects

\begin{tabular}{|c|c|c|c|c|c|c|}
\hline & \multicolumn{6}{|c|}{ Dependent variable: } \\
\hline & \multicolumn{6}{|c|}{ Probability of PPG Bond Issuance } \\
\hline & (1) & (2) & (3) & (4) & $(5)$ & $(6)$ \\
\hline $\log (\mathrm{GDPpc})(\mathrm{t}-1)$ & $\begin{array}{l}0.244^{*} \\
(0.101)\end{array}$ & $\begin{array}{l}0.249^{*} \\
(0.101)\end{array}$ & $\begin{array}{l}0.000585 \\
(0.000446)\end{array}$ & $\begin{array}{l}0.246^{* *} \\
(0.0793)\end{array}$ & $\begin{array}{l}0.241^{* *} \\
(0.0798)\end{array}$ & $\begin{array}{l}0.0581 \\
(0.366)\end{array}$ \\
\hline GDP growth (t-1) & $\begin{array}{l}-0.0165 \\
(0.0155)\end{array}$ & $\begin{array}{l}-0.0190 \\
(0.0135)\end{array}$ & $\begin{array}{l}-0.0000200 \\
(0.0000274)\end{array}$ & $\begin{array}{l}-0.00310 \\
(0.00771)\end{array}$ & $\begin{array}{l}-0.00356 \\
(0.00770)\end{array}$ & $\begin{array}{l}-0.000376 \\
(0.00247)\end{array}$ \\
\hline Current Account to GDP (t-1) & $\begin{array}{l}0.00638 \\
(0.0107)\end{array}$ & $\begin{array}{c}0.00443 \\
(0.00785)\end{array}$ & $\begin{array}{l}0.0000374 \\
(0.0000489)\end{array}$ & $\begin{array}{l}0.00479 \\
(0.00313)\end{array}$ & $\begin{array}{l}0.00421 \\
(0.00308)\end{array}$ & $\begin{array}{l}0.000660 \\
(0.00431)\end{array}$ \\
\hline Reserves Assets/Months of Imports (t-1) & $\begin{array}{l}-0.0477 \\
(0.0589)\end{array}$ & $\begin{array}{l}-0.0497 \\
(0.0581)\end{array}$ & $\begin{array}{l}-0.0000560 \\
(0.0000861)\end{array}$ & $\begin{array}{l}-0.0632 \\
(0.0382)\end{array}$ & $\begin{array}{l}-0.0658 \\
(0.0355)\end{array}$ & $\begin{array}{l}-0.00261 \\
(0.0176)\end{array}$ \\
\hline Government Debt to GDP (t-1) & $\begin{array}{l}-0.00327 \\
(0.00367)\end{array}$ & $\begin{array}{l}-0.00356 \\
(0.00347)\end{array}$ & $\begin{array}{l}-0.000000387 \\
(0.00000630)\end{array}$ & $\begin{array}{l}-0.00148 \\
(0.00260)\end{array}$ & $\begin{array}{l}-0.00194 \\
(0.00249)\end{array}$ & $\begin{array}{l}-0.000401 \\
(0.00265)\end{array}$ \\
\hline Inflation (t-1) & $\begin{array}{c}-0.0132 \\
(0.00993)\end{array}$ & $\begin{array}{l}-0.0139 \\
(0.0100)\end{array}$ & $\begin{array}{l}-0.00000411 \\
(0.0000188)\end{array}$ & $\begin{array}{l}-0.0151 \\
(0.00906)\end{array}$ & $\begin{array}{c}-0.0147 \\
(0.00895)\end{array}$ & $\begin{array}{l}-0.000382 \\
(0.00277)\end{array}$ \\
\hline Private Credit to GDP (t-1) & $\begin{array}{l}-0.00471 \\
(0.00283)\end{array}$ & $\begin{array}{l}-0.00523 \\
(0.00272)\end{array}$ & $\begin{array}{l}-0.0000401 \\
(0.0000517)\end{array}$ & $\begin{array}{l}-0.00385^{*} \\
(0.00195)\end{array}$ & $\begin{array}{l}-0.00382 * \\
(0.00192)\end{array}$ & $\begin{array}{l}-0.000927 \\
(0.00608)\end{array}$ \\
\hline IMF Support & $\begin{array}{l}-0.0457 \\
(0.0517)\end{array}$ & $\begin{array}{l}-0.0462 \\
(0.0546)\end{array}$ & $\begin{array}{l}-0.000130 \\
(0.000123)\end{array}$ & $\begin{array}{l}-0.0812 \\
(0.0636)\end{array}$ & $\begin{array}{l}-0.0814 \\
(0.0625)\end{array}$ & $\begin{array}{l}-0.00252 \\
(0.0162)\end{array}$ \\
\hline Rule of Law (t-1) & $\begin{array}{l}0.00554 * \\
(0.00232)\end{array}$ & $\begin{array}{l}0.00553 * \\
(0.00219)\end{array}$ & $\begin{array}{l}0.0000393 \\
(0.0000445)\end{array}$ & $\begin{array}{l}0.00424 * \\
(0.00165)\end{array}$ & $\begin{array}{l}0.00448 * * \\
(0.00165)\end{array}$ & $\begin{array}{l}0.000264 \\
(0.00140)\end{array}$ \\
\hline VIX Index & $\begin{array}{c}-0.0367 * * \\
(0.0135)\end{array}$ & $\begin{array}{c}-0.0363 * * \\
(0.0129)\end{array}$ & $\begin{array}{l}-0.0000291 \\
(0.0000426)\end{array}$ & $\begin{array}{l}-0.0208 \\
(0.0118)\end{array}$ & $\begin{array}{l}-0.0188^{*} \\
(0.00955)\end{array}$ & $\begin{array}{l}-0.000996 \\
(0.00656)\end{array}$ \\
\hline US growth & $\begin{array}{c}0.0963 \\
(0.0534)\end{array}$ & $\begin{array}{l}0.0923 * \\
(0.0464)\end{array}$ & $\begin{array}{l}0.0000315 \\
(0.0000773)\end{array}$ & $\begin{array}{c}0.0257 \\
(0.0182)\end{array}$ & $\begin{array}{c}0.0219 \\
(0.0156)\end{array}$ & $\begin{array}{l}0.000883 \\
(0.00610)\end{array}$ \\
\hline BCOM Index & $\begin{array}{l}0.0303 * \\
(0.0145)\end{array}$ & $\begin{array}{l}0.0296^{*} \\
(0.0148)\end{array}$ & $\begin{array}{c}0.0000511 \\
(0.0000475)\end{array}$ & $\begin{array}{c}0.00999 \\
(0.00687)\end{array}$ & $\begin{array}{c}0.00752 \\
(0.00626)\end{array}$ & $\begin{array}{l}0.000890 \\
(0.00515)\end{array}$ \\
\hline EMBI & $-0.000442 *$ & $-0.000464 *$ & -0.000000325 & & & \\
\hline
\end{tabular}

\section{CInternational Monetary Fund. Not for Redistribution}


$\begin{array}{lll}(0.000214) & (0.000208) & (0.000000480)\end{array}$

\begin{tabular}{ccccccc}
\hline RE Logit & Yes & No & No & Yes & No & No \\
RE Probit & No & Yes & No & No & Yes & No \\
Conditional Logit (Country FE) & No & No & Yes & No & No & Yes \\
Observations & 103 & 103 & 102 & 183 & 183 & 165 \\
\hline Robust and clustered standard errors by country. & & & $* \mathrm{p}<0.1 ; * * \mathrm{p}<0.05 ; * * * \mathrm{p}<0.01$
\end{tabular}


Table 11C: Probability of Issuance regressions - LPM

\begin{tabular}{|c|c|c|c|c|c|c|c|c|}
\hline & \multicolumn{8}{|c|}{ Dependent variable: } \\
\hline & \multicolumn{8}{|c|}{ Probability of PPG Bond Issuance } \\
\hline & (1) & $(2)$ & (3) & (4) & $(5)$ & (6) & (7) & (8) \\
\hline \multirow{2}{*}{$\log (\mathrm{GDPpc})(\mathrm{t}-1)$} & 0.192 & 0.652 & $0.248^{* *}$ & 1.201 & $0.196^{*}$ & 0.657 & $0.192 *$ & 0.473 \\
\hline & $(0.103)$ & $(0.797)$ & $(0.0934)$ & $(1.171)$ & $(0.0782)$ & $(0.604)$ & $(0.0756)$ & $(0.730)$ \\
\hline \multirow{2}{*}{ GDP growth (t-1) } & -0.0109 & -0.0108 & -0.0110 & -0.00857 & 0.000797 & -0.00640 & 0.00109 & -0.00678 \\
\hline & $(0.0138)$ & $(0.0120)$ & $(0.0119)$ & $(0.0118)$ & $(0.00922)$ & $(0.00914)$ & $(0.00904)$ & $(0.00898)$ \\
\hline \multirow{2}{*}{$\begin{array}{l}\text { Current Account to GDP (t- } \\
\text { 1) }\end{array}$} & 0.00305 & $0.0369 * * *$ & 0.000836 & $0.0380 * *$ & 0.00439 & 0.00677 & 0.00413 & 0.00633 \\
\hline & $(0.00683)$ & $(0.00676)$ & $(0.00645)$ & $(0.0104)$ & $(0.00284)$ & $(0.00352)$ & $(0.00297)$ & $(0.00356)$ \\
\hline \multirow{2}{*}{$\begin{array}{l}\text { Reserves Assets/Months of } \\
\text { Imports ( } \mathrm{t}-1)\end{array}$} & -0.0403 & -0.114 & -0.0286 & -0.0646 & $-0.0681^{*}$ & $-0.0907 *$ & -0.0545 & $-0.0792 *$ \\
\hline & $(0.0482)$ & $(0.0642)$ & $(0.0442)$ & $(0.0667)$ & $(0.0294)$ & $(0.0331)$ & $(0.0307)$ & $(0.0342)$ \\
\hline \multirow{2}{*}{$\begin{array}{l}\text { Government Debt to GDP } \\
\qquad(\mathrm{t}-1)\end{array}$} & -0.00203 & -0.00295 & -0.00296 & -0.00602 & -0.000685 & -0.00482 & -0.000104 & -0.00459 \\
\hline & $(0.00279)$ & $(0.00653)$ & $(0.00289)$ & $(0.00751)$ & $(0.00194)$ & $(0.00417)$ & $(0.00220)$ & $(0.00452)$ \\
\hline \multirow{2}{*}{ Inflation (t-1) } & -0.00970 & -0.00176 & -0.0134 & -0.00823 & -0.00738 & 0.00205 & -0.00923 & -0.0000212 \\
\hline & $(0.0112)$ & $(0.0170)$ & $(0.0105)$ & $(0.0176)$ & $(0.00664)$ & $(0.00785)$ & $(0.00770)$ & $(0.00943)$ \\
\hline \multirow{2}{*}{ Private Credit to GDP (t-1) } & -0.00422 & -0.0350 & -0.00559 & $-0.0503 *$ & -0.00280 & -0.00813 & -0.00316 & -0.00891 \\
\hline & $(0.00309)$ & $(0.0169)$ & $(0.00323)$ & $(0.0195)$ & $(0.00214)$ & $(0.00657)$ & $(0.00216)$ & $(0.00730)$ \\
\hline \multirow{2}{*}{ IMF Support } & -0.0263 & -0.0490 & -0.0187 & -0.00766 & -0.0890 & -0.0634 & -0.0760 & -0.0519 \\
\hline & $(0.0736)$ & $(0.126)$ & $(0.0788)$ & $(0.131)$ & $(0.0697)$ & $(0.0717)$ & $(0.0683)$ & $(0.0678)$ \\
\hline \multirow{2}{*}{ Rule of Law (t-1) } & $0.00376^{*}$ & $0.0398 *$ & $0.00397^{*}$ & $0.0401 *$ & $0.00409^{*}$ & 0.00888 & $0.00408^{*}$ & 0.0100 \\
\hline & $(0.00165)$ & $(0.0151)$ & $(0.00168)$ & $(0.0151)$ & $(0.00200)$ & $(0.00890)$ & $(0.00197)$ & $(0.00857)$ \\
\hline \multirow{2}{*}{ VIX Index } & $-0.0292 * * *$ & -0.0209 & & & $-0.0136 * *$ & $-0.0166^{*}$ & & \\
\hline & $(0.00696)$ & $(0.0133)$ & & & $(0.00521)$ & $(0.00751)$ & & \\
\hline \multirow{2}{*}{ US growth (t-1) } & 0.0343 & -0.0234 & & & 0.00416 & -0.000925 & & \\
\hline & $(0.0379)$ & $(0.0458)$ & & & $(0.0121)$ & $(0.0133)$ & & \\
\hline \multirow{2}{*}{ BCOM Index } & 0.0220 & 0.0412 & & & 0.00294 & 0.0115 & & \\
\hline & $(0.0184)$ & $(0.0286)$ & & & $(0.00680)$ & $(0.0150)$ & & \\
\hline EMBI & -0.000160 & -0.0000583 & -0.0000553 & 0.000192 & & & & \\
\hline
\end{tabular}


53

$\begin{array}{llll}(0.000189) & (0.000225) & (0.000169) & (0.000192)\end{array}$

\begin{tabular}{|c|c|c|c|c|c|c|c|c|}
\hline Constant & $\begin{array}{l}-1.446 \\
(2.294)\end{array}$ & & & & & & & \\
\hline Pooling & Yes & No & No & No & Yes & No & No & No \\
\hline Country FE & No & Yes & No & Yes & No & Yes & No & Yes \\
\hline Time FE & No & No & Yes & Yes & No & No & Yes & Yes \\
\hline Observations & 103 & 103 & 103 & 103 & 183 & 183 & 183 & 183 \\
\hline
\end{tabular}

*Robust and clustered standard errors by country.

${ }^{*} \mathrm{p}<0.1 ; * * \mathrm{p}<0.05 ; * * * \mathrm{p}<0.01$ 
Table 11D: EMBIG regressions - 2009 to 2018

Dependent variable:

EMBIG Index

(1) (2) (3) (4)

\begin{tabular}{|c|c|c|c|c|}
\hline \multirow[t]{2}{*}{$\log (\mathrm{GDPpc})(\mathrm{t}-1)$} & -58.827 & $-1,108.834^{* * *}$ & -47.778 & $-997.252^{* * *}$ \\
\hline & $(74.200)$ & $(284.135)$ & $(73.582)$ & $(347.839)$ \\
\hline \multirow[t]{2}{*}{ GDP growth (t-1) } & $-24.606^{* *}$ & -10.912 & $-22.430^{* *}$ & -9.278 \\
\hline & $(9.639)$ & $(7.507)$ & $(9.632)$ & (7.533) \\
\hline \multirow[t]{2}{*}{ Current Account to GDP (t-1) } & $-7.939^{* *}$ & -5.329 & $-7.691^{* *}$ & $-6.380^{* *}$ \\
\hline & $(3.947)$ & $(3.718)$ & $(3.634)$ & $(3.148)$ \\
\hline \multirow[t]{2}{*}{ Reserves Assets/Months of Imports (t-1) } & $-39.282^{*}$ & $-64.476^{* * *}$ & $-43.008^{* *}$ & $-82.952^{* * *}$ \\
\hline & $(23.725)$ & $(21.937)$ & $(21.744)$ & $(24.900)$ \\
\hline \multirow[t]{2}{*}{ Government Debt to GDP (t-1) } & $4.839^{* *}$ & $8.802^{* * *}$ & $5.543^{* * *}$ & $8.615^{* * *}$ \\
\hline & $(1.879)$ & $(2.762)$ & $(1.964)$ & $(2.476)$ \\
\hline \multirow[t]{2}{*}{ Inflation (t-1) } & 11.139 & $18.706^{* *}$ & $10.742^{*}$ & $19.667^{* * *}$ \\
\hline & $(7.032)$ & $(7.277)$ & $(6.373)$ & $(5.289)$ \\
\hline \multirow[t]{2}{*}{ Private Credit to GDP (t-1) } & -2.414 & $16.413^{*}$ & -2.490 & $18.501^{*}$ \\
\hline & $(2.092)$ & $(8.375)$ & (2.098) & $(9.485)$ \\
\hline \multirow[t]{2}{*}{ IMF Support } & -24.213 & $-91.933^{*}$ & -31.105 & $-101.355^{* *}$ \\
\hline & $(53.112)$ & $(50.171)$ & $(46.296)$ & $(40.278)$ \\
\hline \multirow[t]{2}{*}{ Rule of Law (t-1) } & -1.477 & 0.934 & -2.043 & -1.529 \\
\hline & $(1.123)$ & $(6.138)$ & $(1.294)$ & $(3.079)$ \\
\hline \multirow[t]{2}{*}{ VIX Index } & $13.804^{*}$ & 2.982 & & \\
\hline & $(8.135)$ & $(6.169)$ & & \\
\hline \multirow[t]{2}{*}{ US growth (t-1) } & $63.958^{* * *}$ & $96.118^{* * *}$ & & \\
\hline & (14.001) & $(15.278)$ & & \\
\hline BCOM Index & 8.379 & -1.827 & & \\
\hline
\end{tabular}

BCOM Index

$-1.827$ 
(7.963) (12.067)

(937.324)

\begin{tabular}{|c|c|c|c|c|}
\hline Pooling & Yes & No & No & No \\
\hline Country FE & No & Yes & No & Yes \\
\hline Time FE & No & No & Yes & Yes \\
\hline Observations & 99 & 99 & 99 & 99 \\
\hline $\mathrm{R}^{2}$ & 0.529 & 0.495 & 0.550 & 0.495 \\
\hline Adjusted $\mathrm{R}^{2}$ & 0.464 & 0.339 & 0.441 & 0.273 \\
\hline
\end{tabular}

